\title{
Coping with Risk through Mismatches: Domestic and International Financial Contracts for Emerging Economies ${ }^{\otimes}$
}

\author{
Augusto de la Torre \\ World Bank \\ and \\ Sergio L. Schmukler \\ World Bank
}

February 2, 2004

\begin{abstract}
This paper argues that short termism, dollarization, and the use of foreign jurisdictions are endogenous ways of coping with systemic risks prevalent in emerging markets. They represent a symptom at least as much as a problem. These coping mechanisms are jointly determined and the choice of one of them involves risk tradeoffs. Various conclusions can be derived from the analysis. First, because of the dominance of dollar contracts over short-duration contracts, dedollarization might be much more difficult to achieve than often believed. Second, one-dimensional policies aimed at reducing currency and duration mismatches might just displace risk and not diminish it. Third, as systemic risks rise, the market equilibrium settles in favor of investor protection against price risk (through dollar and short-duration contracts) at the expense of exposure to credit risk. Finally, the option value to litigate in the event of default might explain this equilibrium outcome.
\end{abstract}

JEL classification codes: F33, F34, F36, G15, G18

Keywords: currency mismatch; maturity mismatch; dollarization; financial development

\footnotetext{
$\otimes$ Authors are Senior Advisor, Latin American and the Caribbean Region, and Senior Economist, Development Research Group, respectively. For helpful comments, we are grateful to Ricardo Caballero, Mauricio Cárdenas, Ricardo Hausmann, Eduardo Levy Yeyati, Guillermo Perry, and participants at the IADB/World Bank conference "Financial Dedollarization: Policy Options." We are grateful to Marina Halac for outstanding research assistance. The paper is part of a broader study on capital markets, conducted at the Chief Economist Office, Latin America and the Caribbean Region, World Bank. The views in this paper are entirely those of the authors and do not necessarily represent the views of the World Bank.

E-mail addresses: adelatorre@ worldbank.org and sschmukler@worldbank.org
} 


\section{Introduction}

Economists tend to agree that achieving financial sector development, as manifested in the triad of deep domestic markets for long-duration financial contracts denominated in domestic currency, is paramount. The reason is that financial depth has been positively linked to economic growth and negatively associated with the incidence of financial crises. ${ }^{1}$ A typical emerging economy, however, features one or a combination of a high degree of short termism, financial dollarization, and illiquid domestic financial markets (illiquid not only because of small size but also because domestic residents prefer to keep the financial wealth in foreign, safer jurisdictions). In light of the benefits of financial development, many policy actions have been suggested. As characterized by Tirole (2002), the conventional policy advice calls for eliminating currency and maturity mismatches, upgrading institutional infrastructures, enhancing prudential oversight and transparency, and choosing the appropriate exchange rate regime. Notwithstanding the consensus on this type of policy prescription and the intensity of financial sector reform and crisis-prevention efforts, why does financial development remain so elusive a goal for most emerging countries? Why, in particular, do currency and duration mismatches continue to be a widespread and recurring feature of these countries' financial landscape, despite their well-known risks and adverse effects on vulnerability to shocks and growth? ${ }^{2}$ In this paper, we try to provide new answers to these questions.

We argue that the resort to short-duration peso contracts and dollar contracts at home, as well as to dollar contracts in a foreign jurisdiction, are rational responses of agents operating in a globalized market and trying to cope with the high systemic risks of emerging economies. Systemic risks include price risk (interest rate and exchange rate volatility), price-induced default risk, loss given default (due to poor contract enforcement institutions), and dilution and confiscation risks derived from sovereign-related dualagency and time inconsistency problems. In an environment of high systemic risk, currency and duration mismatches in domestic and international contracts that involve emerging market assets are risk-mitigating mechanisms. They are a solution at least as much as a problem - a solution with bad side effects, to be sure, but a solution nonetheless. Given that these risk-coping devices are there for a reason, it is difficult to ascertain whether their incidence is "excessive" (in some normative sense) and their elimination cannot be free of costs.

\footnotetext{
${ }^{1}$ For more than a century, economists have emphasized the importance of financial development for economic growth. Historically, the literature focused on the role of banks, beginning with Bagehot (1873) and Schumpeter (1911). More recently, empirical work by Atje and Jovanovic (1993), King and Levine (1993), and Levine and Zervos (1998) have documented that financial development leads to growth. Several papers have addressed concerns about causality, including Beck and Levine (2002), Levine, Loayza, and Beck (2000), Demirguc-Kunt and Maksimovic (1998), and Rajan and Zingales (1998).

${ }^{2}$ Calvo, Izquierdo, and Talvi (2003) argue that liability dollarization raises vulnerability to sudden stops in capital flows. Levy Yeyati (2003a) presents evidence suggesting that financial dollarization is associated with lower and more volatile growth.
} 
The short-duration, dollarization, and internationalization of financial contracts involving emerging market assets are features that have received wide attention in the economic debate. At least two major strands of the literature have studied these issues, reaching different diagnoses as to the root causes of the problem and, hence, emphasizing different policy solutions. One relevant strand comes from the open macro/international finance camp. The other one is from the financial development camp.

The open macro/international finance camp has discussed the maturity and currency composition of contracts, mainly in connection with recent financial crises, starting in particular with the Mexican crisis of 1994-95. This literature has stressed that short-term debt makes economies vulnerable to crises (Caballero and Krishnamurthy 1998; Calvo 1995, 1998; Calvo and Mendoza 1996; Chang and Velasco 2000, 2001; Furman and Stiglitz 1998; Sachs, Tornell, and Velasco 1996). It has also argued that dollar debts among non-dollar earners constitute a source of instability, as exchange rate devaluations have adverse balance sheets effects (Eichengreen and Hausmann 1999; Frankel and Rose 1996). With capital flows and financial issues taking center stage, some have proposed formal dollarization as a way to stabilize and develop financial markets in a globalized context (Calvo and Reinhart 2000; Hausmann et al. 1999). Others, especially after the Argentine crisis, have argued that dollarization would rather increase vulnerability and, hence, have recommended a flexible exchange rate regime underpinned by inflation targeting, which can help dedollarize economies (Mishkin and Savastano 2001; Goldstein 2002). ${ }^{3}$ While bitterly at odds, dollarizers and floaters within this camp have in common an emphasis on the exchange rate system to achieve financial and macro stability. The tendency in this camp until recently has been to leave institutions in the background. ${ }^{4}$ This is beginning to change, as some have started to highlight the need to focus on fundamental institutions, even suggesting that the emphasis on exchange rate regimes is simply misguided (Calvo and Mishkin 2003; de la Torre, Levy Yeyati, and Schmukler 2002).

The financial development camp has studied currency and duration mismatches from a different angle. The emphasis has been on overcoming such mismatches as part of the development of domestic financial systems toward the depth, efficiency, and soundness levels found in industrial countries. The initial focus was on freeing emerging markets from the grip of "financial repression"-i.e., small financial markets due to excessive state intervention (Bekaert, Harvey, and Lundblad 2001; Henry 2000; Jayaratne and Strahan 1996; La Porta, Lopez-de-Silanes, and Shleifer 2000; Levine 2001). This led initially to a simplistic policy prescription: liberalize the domestic financial system and the capital account as the road to efficiency via competition. Shaken subsequently by the lack of visible development and financial crises, this approach was forced to question the sequencing of policy reform and has turned the attention toward regulatory institutions,

\footnotetext{
${ }^{3}$ For discussions on alternative ways out of the Argentine currency board, see Hausmann (2001) and de la Torre, Levy Yeyati, and Schmukler (2003).

${ }^{4}$ To be sure, dollarizers are aware of institutional weaknesses and are often charmed by the idea that dollarization could help make up for such weaknesses. Floaters tend to focus on a subset of institutions, particularly independent central banks and fiscal institutions.
} 
legal frameworks, market infrastructures, safety nets, and contract enforcement (Caprio and Hanson 2001; Demirgüç-Kunt and Detragiache 2001; Kaminsky and Schmukler 2002; La Porta, Lopez-de-Silanes, and Shleifer 2002). The tendency in this camp has been to leave macroeconomic issues, and particularly currency issues, in the background while focusing on building domestic markets and their institutional infrastructure.

Relative to the existing literature, this paper is a first and tentative attempt to tackle the issues of duration, currency, and jurisdiction jointly and within an integrated conceptual framework. This analysis highlights important points, including the following. First, a dollar contract dominates over a short-duration peso contract as a risk-coping mechanism, making dedollarization much more difficult to achieve than often believed. Second, actions geared at eliminating the symptoms (short-duration, dollarization) without addressing the underlying causes (such as macroeconomic policy volatility, deficient creditor rights systems, and weak institutional infrastructures) will affect risk allocation. In particular, a one-dimensional effort to reduce the use of one coping mechanism may simply result in risk displacement (e.g., a compensating increase in the use of another coping mechanism) rather than risk reduction. Third, short-duration peso contracts and dollar contracts are coping devices that entail inevitable tradeoffs-they help hedge against price (interest rate and exchange rate) risk at the expense of exposure to priceinduced default (credit) risk. Moreover, as systemic risks rise, the market equilibrium in financial contracting settles in favor of investor protection against price risk (through dollarization and short duration) at the expense of exposure to price-induced credit risk, instead of the other way around. Fourth, the option value to litigate in the event of default might help explain this equilibrium outcome. Such option value is higher when exercised in better contract enforcement institutional settings. As a consequence, other things equal, improvements in contract enforcement institutions or increases in the debtor's capital buffer-both of which reduce losses given default-might encourage investors to incur more (rather than less) credit risk exposure, particularly through contract dollarization.

In the remainder of this paper, Section 2 analyzes the risks of contracting in emerging economies. Section 3 studies how duration, currency, and jurisdiction are used to deal with those risks. Section 4 shows how these coping mechanisms are used in practice in emerging economies. Section 5 presents some final remarks.

\section{Contracting in Emerging Markets: Systemic Risks}

The major difference between financial contracting in developed and emerging countries arises from the presence of significantly higher systemic risks in the latter. Almost by definition, developed countries feature mature and high-quality institutions that underpin high standards of macroeconomic stability, financial system regulation, and contract enforcement. These strengths include a wide range of relatively well-functioning market and non-market infrastructures-including in the legal, accounting, disclosure, debtor information, and corporate governance fields-as well as a shared sense of confidence in the law and judiciary. All of these features provide a fertile terrain for financial contracts to blossom. The combination of macroeconomic stability and sound 
institutional performance in developed countries constitutes a system-wide asset, a public good that benefits all financial contracts written and enforced within developed country jurisdictions. As a result, financial contracts are empowered to provide effective solutions to idiosyncratic risks and incentive problems, such as those that arise, at the individual transaction level, from the well-known problems of time inconsistency, information asymmetry, uncertainty, and transaction (including enforcement) costs.

Financial contracting in emerging economies is a very different matter-it has to anticipate a rather wild ride. A shift from developed to emerging markets is typically met with a rise in systemic risks. The riskiness and precariousness of the contracting environment constitutes a system-wide liability, a sort of public "bad" that undermines the writing and enforcement of financial contracts across the board. In the rest of this section we characterize and discuss some of the salient systemic risks in emerging markets.

System-wide risks have their origins in institutional weaknesses but also in noninstitutional factors. The institutions that matter for systemic risks are not only those directly related to macroeconomic stability (i.e., fiscal and monetary institutions) and to the quality of the contractual environment, but also the more fundamental ones that underpin overall governance in a society-including political democracy and the judiciary. Non-institutional factors, such as geographic and initial endowment limitations (including small economic size) and commodity-dependent productive structures, can raise systemic risks too. For example, smallness could limit opportunities for risk reduction via diversification, thwart the emergence of scale economies and network externalities, and restrict the scope for liquidity. Also, commodity dependent exports could lead to macroeconomic instability via terms-of-trade volatility.

The key argument in this section is that an environment of high systemic risk substantially complicates financial contracting. Even abstracting from the possibility of government intentional interference with financial contracts, there are significant systemic risks that undermine the capacity of lenders to deal effectively with the agency problems that are pervasive in finance. ${ }^{5}$ Potential government interference with financial contracts dramatically exacerbates the situation. Systemic risks affect and are affected by the actions of the emerging country sovereign. In particular, they widen the scope for dualagency problems-i.e., the possibility of government actions geared at altering, in one way or another, the value or the terms of contracts between private parties. Dual-agency problems, in turn, boost systemic risks. Let us now explain this argument in some detail.

To keep the discussion manageable we limit the set of contracts under analysis to: (i) saving/borrowing contracts, in which time and uncertainty are of the essence and where the currency acts in its function of store of value; (ii) contracts that involve an emerging country resident (at least at one end of the contract) and emerging country assets. The

\footnotetext{
${ }^{5}$ Single-agency problems are specific to an individual contract between a debtor and a creditor. For example, having received the loan, the debtor (agent) may undertake actions that are not in line with the financier's interests. Common-agency problems arise from contracting externalities, free-rider problems, and heterogeneity of claims (Tirole 2002).
} 
first cut excludes a wide range of contracts-for example, payment, equity, or insurance contracts. The second cut, however, leaves a broader set than implied by the traditional measure of a country's financial development, which typically considers only the financial contracts written in the domestic jurisdiction. Our set encompasses all lending/borrowing contracts that involve emerging country assets, regardless of the jurisdiction in which the contracts are written.

We also limit the set of systemic risks under analysis, focusing mainly on price and default risks and on the added complications once sovereign-related dual-agency and time inconsistency problems are brought into the picture. At a first level, abstracting from sovereign-related problems, financial contracts live under the influence of two main system-wide factors: (i) volatility in macro prices such as the (peso) interest rate and the exchange rate (which reflect in part, but not exclusively, deficiencies in fiscal and monetary institutions), ${ }^{6}$ and (ii) weaknesses in institutional infrastructures that are germane to the efficient writing and enforcement of financial contracts (particularly the frameworks for post-default contract renegotiation and litigation, including collateral repossession processes and bankruptcy proceedings). These factors affect financial contracts across the board and give rise to at least three types of systemic risks-price risk, price-induced default risk (probability of default), and risk of loss given default (severity of default). The prices considered here are the interest and exchange rates.

At this first level, therefore, risk averse investors have to worry about the uncertainty over the future path of the interest and exchange rates (price risk), which translates into difficulties in expectation formation and is evidenced by a high incidence of deviation of these variables from their expected levels. In addition, investors have to worry about price-induced credit risk-i.e., the probability of default resulting from the erosion in the debtor's capacity to pay due to an unexpected increase in the interest or exchange rates (i.e., the downside of price risk). ${ }^{7}$ Finally, investors have to worry about the severity of default-i.e., the losses in the event of default, which are higher in emerging markets, given significant shortcomings in the regulatory and institutional frameworks for post-default contract renegotiation, litigation, and enforcement.

Enter now sovereign-related time inconsistency and dual-agency problems. This lifts the discussion to a second, more complex level. While at a first level it is clear that the policies of the sovereign are a determinant of the systemic risks, at this second level it becomes equally clear that the systemic risks themselves can influence the actions of the sovereign. The emerging country sovereign lives alongside private residents in an environment of high systemic risk and, as a result, may feel compelled by the very logic of such risks to act in certain ways with respect to its own liabilities or financial contracts among private parties. The ensuing actions may thus not necessarily reflect the whims of

\footnotetext{
${ }^{6}$ Interest and exchange rate volatilities are just two of the multiple manifestations of volatility in emerging economies, which is significantly higher than that in developed countries. This has been amply documented elsewhere (IADB 1995; De Ferranti et al. 2000).

${ }^{7}$ Notice that, in discussing the systemic dimensions of default risk, we explicitly leave out considerations regarding willingness to pay.
} 
a rapacious government, as commonly believed. These actions may, for example, reflect the intentions of an ex-ante well-motivated sovereign that is forced ex-post into intrusive behavior vis-à-vis financial contracts, to avoid the materialization of high systemic risks or deal expeditiously with the consequences of such materialization.

In particular, the possibility of purposeful actions by the sovereign vis-à-vis financial contracts gives rise to two additional systemic risks-dilution risk and confiscation risk - that can drastically complicate the previously described risks. Dilution risk is the threat that the sovereign in the emerging economy, as issuer of the peso, might face incentives to liquefy peso liabilities through surprise inflation. This risk affects not just the sovereign's peso debts but all contracts denominated in nominal pesos, regardless of the jurisdiction in which they are written. The insidiousness of dilution risk resides in that it can obliterate contract value without breaching any contractual clause. Dilution risk can arise from the time inconsistency problem-once the government has raised money by placing nominal peso liabilities, it may subsequently have incentives to inflate its own liabilities away when faced with extreme budgetary constraints. Dilution risk can also arise from the dual-agency problem, as the government may face incentives to act as an outside agent and dilute peso contracts between private agents in which the government does not explicitly participate. It is conceivable, in effect, that a government with apparently viable fiscal accounts but captured by powerful lobbies of large debtors and/or bankers may choose to engineer an inflation spiral to bail them out. Dilution risk is conceptually different from, but often intertwined with, macro price risk. ${ }^{8}$ Dilution risk can lurk ominously behind price risk.

Confiscation risk is the menace of a forcible breach of financial contracts imposed administratively by the emerging economy sovereign. While dilution risk can melt away the real value of contracts without breaking contractual clauses, confiscation risk is the threat that contractual clauses themselves may be altered by sovereign decree. While dilution risk, if materialized, would extend automatically to all private sector peso denominated contracts (even if that was not part of the government's initial intention), the tampering by the government with contractual clauses in its own liabilities does not carry automatically to private sector contracts. Explicit premeditation is needed for the government to intrude with clauses in contracts between private parties. As with dilution, confiscation risk can arise from time inconsistency problems (e.g., leading to a unilateral reprogramming by the government of its own obligations) or from dual-agency problems (e.g., leading to actions that favor the position of domestic borrowers at the expense of their foreign creditors or, as in the recent crises of Ecuador and Argentina, in sovereign decrees that forcibly freeze, reprogram, or securitize bank deposits). ${ }^{9}$ Confiscation mischief can get to private contracts indirectly-for example, the government could

\footnotetext{
${ }^{8}$ For example, agents may anticipate high interest rate volatility for reasons other than concerns about lack of fiscal viability and consequent dilution risk-e.g., a monetary policy geared at stabilizing the currency in times of capital flow instability.

9 Tirole (2002) emphasizes dual-agency problems in cross-border lending-the government may have incentives to favor local debtors over foreign lenders because, for example, the latter do not vote.
} 
arbitrarily tinker with the measurement of an index (or the indexing formula) used in financial contracts. ${ }^{10}$ Confiscation risk can lurk ominously behind default risk.

In conclusion, even in the absence of sovereign purposeful intrusion, system-wide price and default risks arise from the conjunction of macro price volatility and poorly functioning institutional infrastructures for post-default contract renegotiation or litigation. These are sufficient to undermine the ability to deal effectively with agency problems when subscribing financial contracts that involve emerging market assets. Other, more far-reaching systemic risk dimensions arise from sovereign-related time inconsistency and dual-agency problems. These complicate further, and even more dramatically, financial contracting in emerging economies.

\section{Contracting in Emerging Markets: Risk-Coping Mechanisms}

How do agents subscribing financial contracts in emerging economies deal with the mentioned systemic risks? A first and obvious response is to simply reduce engagement in financial contracting or not contract at all. It is thus not surprising that emerging financial systems tend to be shallow. There is, in effect, ample empirical evidence that the depth of domestic financial systems (as measured, for example, by the ratio of $\mathrm{M} 2$, private sector credit, or equity market capitalization to GDP) is inversely related to macroeconomic volatility (IADB 1995). And to the extent that the mentioned system-wide risks arise from institutional weaknesses, there is equally abundant and persuasive evidence that the low quality of institutions constitute an independent and fundamental determinant of low financial depth (La Porta, Lopez-de-Silanes, Shleifer, and Vishny 1997). The mentioned risks can, furthermore, prevent the development of domestic markets for certain financial products, either because uncertainty is so high as to render the risk pricing impossible or because the risks raise the price of certain financial products to levels where demand does not exist. As a result, the mentioned systemic risks in emerging economies can lead not just to shallow systems but also to significantly less diversified ones-i.e., systems with missing markets for financial products that are commonly found in developed economies.

In this section, we focus not on the depth of financial systems or the missing markets therein, but rather on the way in which existing financial contracts are adapted to cope with system-wide risks of emerging economies. Existing financial contracts not only reveal the level of investor appetite for systemic risk (for a given return) but also the particular manner in which investors take on systemic risk exposure (e.g., through certain combinations of contracts and not others). Because of financial underdevelopment, which itself is not independent of the high systemic risks, explicit hedges (such as derivative products) are not normally available in emerging markets to achieve full defeasance of the mentioned systemic risks. Therefore, financial contracts that involve emerging economy assets have to resort to what we call "risk-coping mechanisms." We examine three types

${ }^{10}$ Examples of such indices include the dollar and the consumer price indices. A dollar-linked financial contract could be forcibly breached, for example, if the government were to establish, by decree, that the link would be switched to the official (fixed) exchange rate, rather than the free market one. 
of financial contracts that can play such role-dollar contracts, short-duration peso contracts, and contracts written in a foreign jurisdiction. ${ }^{11}$

Domestic financial market liberalization, technological and financial innovation, and international financial integration have enhanced the availability and affordability of these coping mechanisms to emerging country residents. Of the three mechanisms, short duration was virtually the only one open to residents in a closed and "repressed" emerging economy. Over the past decades, however, residents in an increasing number of emerging countries have been able to denominate financial contracts in hard currency ("dollars"). Historically, governments have lifted restrictions on dollar intermediation to avoid the credit disruptions caused by the sudden flights of capital abroad, triggered by expectations of currency devaluation. Where financial intermediation in dollars is allowed, residents can switch to the dollar without leaving the country, which insulates domestic (dollar) credit from defensive behavior induced by devaluation fears. ${ }^{12}$ Also, with greater integration into international financial markets and facilitated by innovations in financial product and information technology, residents of an emerging economy, particularly the larger and more solvent ones, can break free to an extent from the risks associated with weak domestic institutions by writing financial contracts in a developed country jurisdiction. (For simplicity, throughout this paper, by "foreign jurisdiction" we mean the jurisdiction of a developed country.) In sum, financial liberalization and globalization have reduced the transaction costs of contracting in dollars or in a foreign jurisdiction in order to find refuge from systemic risks in emerging markets. As a result, these risks have become diversifiable to an extent, but not without tradeoffs and costs, as discussed below.

By focusing on these three risk-coping mechanisms, we do not intent to suggest that they are the only important ones. The list can indeed be expanded to include other well-known coping devices, such as the over-reliance on real estate collateral and undue resort to connected lending (loans to related parties). Both are broadly used to deal with system-wide risks in emerging economies arising from information opacity (including due to unreliable accounting and disclosure practices) and weaknesses in the institutional infrastructures relevant for contract writing and enforcement. ${ }^{13}$ While these latter coping

11 Duration is the weighted average maturity of a financial contract, where the weights arise from the contractual periodicity with which the interest rate adjusts. If the interest rate is fixed for the life of the contract, maturity and duration coincide. Duration is shorter than maturity if the interest rate is contractually adjusted within the life of the contract, and the excess of maturity over duration is larger with more frequent interest rate adjustments. The longer the duration of a financial instrument, the more it exposes the investor (debtor) to losses (gains) as a result of increases (decreases) in the market interest rate.

${ }^{12}$ In some countries, such as Ecuador, Guatemala, and Costa Rica, a similar effect was achieved by allowing (de facto if not de jure) local banks to offer deposit taking and lending services to residents through subsidiaries licensed in an offshore-typically Caribbean-jurisdiction. This "solution" can lead to significant financial vulnerability, however, to the extent that offshore activity is inadequately regulated and supervised. In recent years, authorities in those countries have been taking actions either to eliminate that type of offshore activity and bring it onshore, or to subject it (mainly via agreements with host supervisors) to similar standards of regulation and supervision that apply to onshore entities.

${ }^{13}$ Rajan and Zingales (2003) argue (pp.30-32) that the "tyranny of collateral" arises in markets where the financial infrastructure is inadequate to resolve the problems of uncertainty, adverse selection, or moral hazard. They also argue (p. 34) that "insider-lending practices [are] a solution to primitive informational 
mechanisms are left out of the discussion in this paper, our conceptual framework and method of analysis could be easily extended to cover them too. That said, let us now focus on those mechanisms that constitute the subject matter of this paper.

The discussion in this section is organized around Table 1, which summarizes the risk-coping roles of duration, currency, and jurisdiction in contracts involving emerging economy assets. The table depicts their hedging functions from the viewpoint of the investor (lender), and assumes that investor welfare is measured in terms of non-tradables, so that the real interest and exchange rates are scaled by the consumer price index (CPI). For simplicity, Table 1 assumes that the borrower in a contract derives her income from the non-tradable sector of the economy. Dimmed text indicates that the coping mechanism in question is less effective in dealing with a given risk compared to another mechanism in the same row.

The discussion incorporates key principles of portfolio theory. In particular, we assume that investors will use combinations of short-duration peso contracts, dollar contracts, and contracts written in a foreign jurisdiction in their portfolios so as to diversify and transform their exposure to systemic risks. In addition, we assume that investors may not be compensated in full through the return on a given financial contract for risks that are diversifiable in some regard through the use of other contracts (coping mechanisms). For example, if the interest rate in a long-duration peso contract does not compensate an investor fully for the risk of unexpected changes in inflation, such risk will be hedged via, say, a dollar contract. Similarly, if the interest rate on a contract written at home does not compensate investors in full for confiscation risk, such risk will tend to be diversified away by writing the contract in a foreign jurisdiction.

The discussion is divided into three subsections. The first analyzes the roles of the coping mechanisms when dealing with the systemic dimensions in price-related risksnamely, price risk proper, the probability of default associated with the downside of price risk, and dilution risk. The second subsection examines the functions of the coping mechanisms in terms of avoiding confiscation risk and mitigating losses given default. It highlights the value of the "litigation option" available to the lender through dollar contracting, and especially through dollar contracting in a foreign jurisdiction. The third subsection recapitulates the main messages that emerge from the analysis, and argues that the litigation option of a claim can help explain why, under a high systemic risk environment, the market equilibrium tends to settle in favor of contracts that hedge price risk at the expense of exposure to default risk.

\subsection{Coping with Price, Price-Induced Default, and Dilution Risks}

The first thing to note about price, price-induced default, and dilution risks is that they are jurisdiction invariant. The exposure of contracts involving emerging market

and contractual infrastructure," noting that "historical studies indicate that lending to related parties reflects financial underdevelopment ... rather than some cultural propensity towards being devious." 
assets to these risks is the same regardless of the jurisdiction in which they are written (hence, the jurisdiction column in Table 1 is empty in the rows corresponding to these three risks).

Consider first the ways of coping with price (interest and exchange rate) risk proper. Given a portfolio approach to price risk, what will matter to investors is not the absolute but the relative returns of short- versus long-duration peso contracts and of peso versus dollar contracts. To the extent that the expected differences in returns are incorporated ex-ante in the interest rate spreads (between short- and long-duration peso contracts and between peso and dollar contracts), risk averse investors will focus mainly on the relative volatilities of such returns. Volatilities (and not just expected values) matter to agents that are risk averse. Furthermore, inasmuch as risk averse investors measure their welfare in terms of their consumption, what will ultimately matter to them are the relative volatilities of real prices - that is, of the interest rate and the exchange rate scaled by the price index of an appropriate consumption basket. Hence, in Table 1, the rows corresponding to price risk should be read as the volatility in the real interest rate relative to that of the real exchange rate, and viceversa. Given that the ex-ante volatility in the real interest rate is the other side of the coin of the volatility in the inflation rate, we refer to either of them indistinctly in characterizing interest rate risk.

As indicated in Table 1, both a short-duration contract and a dollar contract enable risk averse investors to cope with an environment where the inflation rate (or equivalently, the real interest rate) is consistently more volatile than the real exchange rate, because these contracts would in this case help stabilize the purchasing power of portfolio returns (as in Ize and Levy Yeyati 2003) or hedge against volatility in labor income (as in Chang and Velasco 2003). At the extreme, a very short duration peso contract (e.g., whose interest rate adjusts overnight) insulates an investor from unexpected changes in the real interest rate almost as effectively as a dollar contract. Short duration and dollarization are near substitutes in this regard. A peso contract, by contrast, allows investors to cope with the opposite environment-one where the uncertainty regarding the real exchange rate systematically exceeds the uncertainty over the real interest rate, provided that investors measure their welfare mainly by their consumption of non-tradables. If investors' consumption is tilted in favor of tradables (which is arguably the case of the wealthy in emerging countries), dollar contracts would better protect the purchasing power of their investment returns against real exchange rate volatility. In sum, investors can cope with real interest and exchange rates volatilities by mixing contracts of different durations and currencies suitably to their portfolios.

Note that, faced with a given price risk, the incentives for savers (lenders) and borrowers are symmetric as regards the choice of currency, but asymmetric regarding the choice of duration. Risk averse savers and borrowers alike would increase the share of dollar contracts in their portfolios (even at an unchanged interest rate differential) to stabilize real portfolio returns or costs, respectively, in response to an increase in the ratio of the variance of the real interest rate (inflation) to the variance of the real exchange rate. 
And both of them would shift toward peso contracting if that ratio decreases. ${ }^{14}$ By contrast, savers and borrowers would move in opposite directions as regards the choice of duration in peso contracts if the ratio of the variance of the real interest rate to the variance of the real exchange rate increases-savers would seek protection in short-duration contracts while borrowers would prefer long-duration contracts.

Enter now the alternatives to cope with the probability of default, which in our framework arises from the downside of real interest and exchange rate risks. ${ }^{15}$ What matters for the default probability is again the ratio of the volatilities of these variables. Portfolio diversification can be also used by investors to reduce the probability of priceinduced default. In particular, a long-duration peso contract shields the debtor's capacity to pay from unexpected increases in the real interest rate, thereby protecting the investor (lender) from real interest rate-induced default risk. And a peso (dollar) contract insulates the lender against real interest rate-induced (real exchange rate-induced) default risk, for analogous reasons.

Note that the same currency will be chosen to cope with a given price risk as well as with the default risk induced by the downside of that price risk. In this sense, it may be said that currency performs double duty. Let us elaborate. If the relevant environment is one where the real interest rate is more volatile than the real exchange rate, risk averse lenders and borrowers would tilt their portfolios in favor of dollar contracts. Such a move would, on the one hand, enable lenders and borrowers to cope with uncertainty regarding the path of the real interest rate (inflation rate) and, on the other hand, insulate the debtor's capacity to pay from the effects of an unexpected increase in the real interest rate, thereby shielding the lender from real interest rate-induced default risk. For analogous reasons, if the relevant environment were reversed-that is, if the variance of the real exchange rate is greater than that of the real interest rate-portfolios would be tilted toward peso contracts, which would then perform the double duty of simultaneously protecting investors that consume in terms of the CPI against real exchange rate risk and real exchange rate-induced default risk.

In contrast with the choice of currency, the choice of duration within peso contracts performs single duty only-it implies a tradeoff between exposure to interest rate risk and exposure to interest rate-induced default risk. A long-duration peso loan protects the lender from real interest rate-induced default risk, but it does so at the expense of increasing her direct exposure to real interest rate instability. The reverse applies to a

\footnotetext{
${ }^{14}$ Ize and Levy Yeyati (2003) have demonstrated this result rigorously, using a minimum variance portfolio (MVP) model that focuses on price risk and abstracts from other risks. In their model, risk averse savers (borrowers) share the same consumption basket and choose the composition of their asset (liability) portfolio so as to stabilize the purchasing power of returns (interest costs). As a result, the share of dollar contracts in the total portfolio (i.e., the degree of financial dollarization) rises with increases in the ratio of the variance of inflation to the variance of the real exchange rate.

${ }^{15}$ An increase in the nominal interest or exchange rate that is exactly matched by an increase in the relevant price (e.g., the product price, if the debtor is a producer, or the wage rate if the debtor is a worker-consumer) leaves the debtor's capacity to pay unaffected.
} 
short-duration peso contract-it shields the saver against interest rate risk by shifting such risk to the borrower, thereby exposing the saver to real interest rate-induced default risk.

The choice of currency, however, presents a different but equally insidious tradeoff-one that can be dubbed "cross-price tradeoff with default risk." In effect, a dollar contract immunizes the investor against both real interest rate (inflation) and real interest rate-induced default risk, but at the expense of making the debtor's capacity to pay vulnerable to an unexpected devaluation of the real exchange rate. That is, when lending in dollars, the investor trades off interest rate risk with exchange rate-induced default risk. Similarly, when lending in pesos, the investor trades off real exchange rate risk with real interest rate-induced default risk (if the contract is of short duration).

Enter now the dilution risk, which can magnify dramatically ex-ante perceptions of inflation volatility, skewing it toward upward inflation spirals. As shown in Table 1, short-duration peso contracts and dollar contracts appear as the coping mechanisms of choice to deal with dilution risk, although dollar contracts are much more effective at that. This is because even a very short-duration peso contract is not completely immune to the risk of being diluted away through a high enough rate of inflation. Moreover, as noted earlier, writing peso contracts in a foreign jurisdiction provides no added protection.

\subsection{Coping with Loss Given Default and Confiscation Risks}

In contrast with the risks in the previous subsection, the loss given default and confiscation risks are jurisdiction sensitive-i.e., writing contracts in a foreign jurisdiction is a way to cope with them.

Once a debtor has defaulted not all is lost for the lender. If the default materializes without governmental interference of contractual clauses, the lender can recover some value through renegotiation (e.g., voluntary workouts) or through formal contract enforcement processes (e.g., collateral repossession and court-sanctioned debtor reorganization or bankruptcy proceedings). If the default is associated with government intrusion-i.e., if it results from the materialization of confiscation risk-the investor (lender) can still use her legal claim to pursue litigation through the courts with a nontrivial likelihood of recovering some value, as illustrated by recent court rulings in Argentina following lawsuits initiated by depositors affected by the forcible "pesification" of their deposits. Thus, regardless of the origins of default, the lender's capacity for postdefault value recovery is inherently linked to the status of a financial contract as legal claim. The legal claim gives its holder a valuable option to renegotiate and litigate. Let us explain this in some detail.

Consider first the case of default not caused by government intrusion. It entails a risk of loss in the process of value recovery, a process that begins once contractual default has occurred or is recognized to be imminent. As indicated in Table 1, a dollar contract is the coping mechanism of choice, particularly if the contract is written in a foreign jurisdiction. Even in the home jurisdiction, where the institutional infrastructure for post- 
default negotiation and litigation is weaker, a dollar contract offers some protection to investors (lenders). To be sure, if the adverse shock in the real interest rate or the real exchange rate is large, the ensuing default would imply a substantial erosion of the value of assets subject to post-default renegotiation or litigation. Nevertheless, for any given magnitude of the shock, a lender will be generally better off in litigation if she holds a dollar claim. This is unambiguously the case if the peso is expected to devalue relative to the dollar, if the interest rate on a peso contract does not fully compensate the investor for loss given default risks (as noted earlier), and if the face value of a claim at the time of default and its currency of denomination are respected as the starting point for renegotiation or litigation (which is the case in virtually all legal systems in the world). Under such conditions, a dollar denominated claim would command a higher recovery value over available assets as compared to a peso claim of equal legal seniority, because the latter would lose purchasing power over time relative to the former. ${ }^{16}$

As shown in Table 1, a dollar claim in a foreign jurisdiction is an even more effective coping mechanism in dealing with the risk mentioned above. The value recovery power of a dollar claim written under the home jurisdiction is limited by the quality of the creditor rights systems and other contract enforcement institutional frameworks at home. At the extreme, if these frameworks are completely dysfunctional, asset value will be inexorably destroyed after default and the dollar denomination of the claim will by itself be of no use. Therefore, it is evident that a dollar claim in a foreign jurisdiction, where contract enforcement institutions are significantly better is, a fortiori, a superior coping mechanism.

Consider now the case of default caused by the materialization of confiscation risk. Short of a quantum leap in institutional infrastructure at home, contracting in a foreign jurisdiction is the only way to capture the benefits of well-functioning contract enforcement and litigation institutions and, hence, of finding safe refuge against confiscation risk. Of course, writing contracts that involve emerging country assets in a foreign jurisdiction is not an option available to every emerging country resident. Corporate debtors wishing to raise finance in a foreign jurisdiction would need to display, for example, a minimum of reliability in terms of information and governance. Moreover, such contracts raise issues for enforcement. In the event of default, a judge in the foreign jurisdiction may rule in favor of the creditor but such ruling may not be enforceable if the debtor has all her assets in the emerging market jurisdiction. A way to mitigate this problem would be for the debtor to post collateral in the form of assets located in the foreign jurisdiction that, as such, could be attached or embargoed pursuant to a judge's ruling. This point should not be exaggerated, however. Even in the absence of attachable collateral, a dollar contract written in the foreign jurisdiction offers the investor superior protection against litigation and confiscation risks because it is costly for an emerging market debtor in default to be also in non-compliance with a ruling issued against her. For starters, such borrower would be denied new finance in the foreign jurisdiction until she complies with the judge's order.

\footnotetext{
${ }^{16}$ This result was rigorously, albeit implicitly, demonstrated in Broda and Levy Yeyati (2001).
} 
The considerations above carry two important implications. The first is that an improvement at home in post-default contract enforcement institutions that leaves all else equal (i.e., that does not materially change the rest of the systemic risks listed in Table 1) would lead to greater (rather than less) dollarization of financial contracts at home. This is simply because the command over value recovery of a dollar claim rises pari passu with better contract enforcement institutions.

The second implication is that-other systemic risks equal-contracts that involve emerging economy assets but are written in a foreign jurisdiction are able to fully capture the benefits of that jurisdiction's strong contract enforcement environment only to the extent that they are denominated in dollars. ${ }^{17}$ This is simply because the value recovery capacity of a peso contract written in a foreign jurisdiction can be undermined by its exposure to price and dilution risks, which are invariant to jurisdiction. Recovery value is maximized with a dollar denominated claim at home and abroad, with a foreign jurisdiction providing, in addition, protection against confiscation risk. This reasoning provides an explanation to the famous "original sin" observation (that neither the sovereign nor the private sector of an emerging economy issue domestic currency debt in international markets), an explanation that is separate and independent from the conventional-wisdom arguments based on moral hazard considerations. ${ }^{18}$

\subsection{Recapitulation and the Prevalence of Default Risk Exposure}

This subsection highlights some messages from Table 1 taken as a whole. It also brings the discussion one step forward by considering the question of why, when systemic risks are high, investors (lenders) prefer contracts that shield them against price risk while exposing them to default risk, instead of the other way around.

A first message of our analysis is the dominance of dollar contracts over shortduration peso contracts as a risk-coping mechanism. To start, a dollar contract is a superior way to deal with price and default risks arising from real interest rate (inflation) volatility-unlike short duration, the dollar performs double duty in this regard. In addition, the dollar trumps short duration when coping with dilution risk. Furthermore, a dollar contract enhances investors' ability to minimize losses and risks in post-default litigation or renegotiation processes, especially when written in a foreign jurisdiction. To top it all, a dollar contract, when written in a foreign jurisdiction, provides refuge from confiscation risk while maximizing the benefits of the well-functioning contract enforcement environment of that jurisdiction. It is thus not surprising to find that the degree of financial dollarization in emerging markets is resiliently high and has been

\footnotetext{
${ }^{17}$ There is a fundamental difference between bonds and depository receipts (DRs) issued in foreign markets. International bonds constitute a contract written in the foreign jurisdiction and under the foreign law. On the other hand, DRs are just receipts of equity issued in domestic jurisdictions and under the domestic law but traded in international markets. One advantage of some DRs vis-à-vis local issues is that they require companies to comply with international governance and accounting standards.

${ }^{18}$ See, for example, Eichengreen, Hausmann, and Panizza (2003).
} 
steadily increasing in most country cases (Honohan and Shi 2002). These considerations also underscore the complex challenges faced by open and financially liberalized emerging economies when trying to establish the local currency (the "peso") as a credible store of value to underpin financial contracts that involve assets of that emerging economy.

Another salient message is that short duration and dollarization entail considerable tradeoffs-that is, they are coping mechanisms with bad side effects. Short duration protects against real interest rate risk, while inevitably increasing exposure to real interest rate-induced default risk. ${ }^{19}$ Dollarization hedges against real interest rate risk at the unavoidable expense of increasing exposure to real exchange rate-induced default risk. In addition, dollarization shields investors vis-à-vis dilution risk but, in the process, it might raise systemic vulnerability to a depositor run (if, for example, depositors anticipate a massive decay in loan quality and erosion of bank solvency in the event of a sharp devaluation of the currency), thereby increasing confiscation risk. The implication appears to be that, in the absence of systemic risk reduction via broad-based improvements in institutional performance, the use of these coping mechanisms can carry the seeds of their own demise.

A third message is that the three coping mechanisms are endogenous responses to, and jointly determined by, an emerging economy's underdeveloped institutional infrastructure and associated systemic risk environment. This implies that, for a given level of systemic risk, a one-dimensional effort geared at reducing the use of a particular coping mechanism can simply result in risk displacement (e.g., a rise in aggregate exposure to price risk in exchange for a reduction in aggregate exposure to price-induced default risk) or in risk balancing via the increase in the use of another coping mechanism (e.g., a rise in short-duration peso contracting mirroring a reduction in dollar contracting). Section 4 presents cross-country evidence on risk balancing.

Finally, the analysis of the inherent tradeoff between price and price-induced default risk has, so far, said nothing on whether and why one should expect emerging markets to settle in favor of exposure to one risk over the other. However, casual observation and the evidence presented in Section 4 suggest that, as systemic risks rise, emerging markets gravitate toward short duration peso contracts and/or dollarized contracts. In other words, the equilibrium outcome in emerging markets favors contracts that hedge against price risk at the expense of exposure to default risk, and not the other way around. Why is that so? The existing explanations of this phenomenon point to precommitment (short-term debt can serve as a commitment mechanism for debtors in a context of time inconsistency); ${ }^{20}$ lack of financial market development; ${ }^{21}$ risk aversion

\footnotetext{
${ }^{19}$ Note that if this implies a shorter maturity structure, there could be an increase in rollover risk, which for the sake of simplicity is not analyzed in this paper. For a detailed analysis on how liquidity and rollover risks play out in emerging markets, see Broner, Lorenzoni, and Schmukler (2003).

${ }^{20}$ Calvo (1988) and Blanchard and Missale (1994) show that the incentives to lower the real value of public debt via inflation is higher when the debt is non-indexed, in domestic currency, and of long-term nature. Rodrik and Velasco (1999) and Jeanne (2000) show that opportunistic governments have more incentives to
} 
(imperfections of capital markets can lead to high effective risk aversion among investors, making long-term too expensive); ${ }^{22}$ and moral hazard (expectations of government bailout of debtors with dollar liabilities, because they are "too big to fail" or "too many to fail", induces lenders to under-price default risk and hence take "excessive" exposure to it). ${ }^{23}$ The analysis in this paper regarding the "litigation option" of a claim throws light on this discussion. It provides an independent explanatory clue. The difficult task of sorting out which explanation is of greater importance is, of course, outside the scope of this paper.

Our point in this connection is that because of the litigation option of a claim, and abstracting from all other competing explanations, the dominant strategy for the creditor is unambiguous: to hedge against price risk and take instead the exposure to credit risk (rather than the other way around). The reason is that the creditor takes default risk in exchange for a legal claim, which has significant value in terms of loss mitigation/recovery if and when the debtor defaults. By contrast, if the creditor chooses exposure to price risk (by shifting toward long-duration peso contracts), she would be protected against default risk but would be left without any loss mitigation recourse in case the interest or exchange rates rise unexpectedly. The legal claim not only allows the creditor to mitigate losses after default via litigation and renegotiation. It also enables creditors to have access to post-default bailout benefits, if any. ${ }^{24}$ Agents that do not hold contractual claims are not only left out of the bailout benefits; they would rather be stuck with the bill as taxpayers. In this sense, the claim and its associated litigation option is more fundamental than moral hazard considerations in determining the revealed preference for credit risk. The claim is a precondition for accessing bailout benefits.

The effect of the litigation option on the prevalence of credit risk exposure is reinforced to the extent that debtors have their own resources at risk. In effect, by lending in dollars or short-duration in pesos the creditor shifts price risk exposure to the debtor, thereby benefiting from the capital buffer in the balance sheet of the debtor. This is because the creditor's exposure to default risk materializes after the debtor's (or the bank's in the case of a deposit contract) capital buffer has been eaten away by an unexpected adverse movement in the real interest or exchange rates. For a given level of risk appetite, the higher the debtor's capital cushion the more creditors will be willing to

carry out reforms when they have to meet early debt repayments. Tirole (2002) explains that short-term and foreign-currency debts reduce the time inconsistency problem.

${ }^{21}$ See Caballero and Krishnamurthy (2003).

22 Broner, Lorenzoni, and Schmukler (2003) argue that countries rely on short-term debt during periods of financial turbulence simply because, in these periods, long-term debt becomes too costly to issue, forcing emerging markets to incur in rollover risks.

${ }^{23}$ See Burnside, Eichenbaum, and Rebelo (2001), Dooley (2000), McKinnon and Pill (1999), and Schneider and Tornell (2001).

24 Post-default bailouts can aim at rescuing debtors directly, in which case lenders and depositors are indirectly but automatically bailed out too. Alternatively, bailouts can aim at rescuing depositors, in which case debtors may be initially left to fend for themselves, although large and influential debtors can subsequently mount strong lobbies to receive direct bailout benefits, as illustrated, for example, by the developments in the aftermath of the 1999 Ecuadorian financial crisis. 
trade price risk exposure in exchange for credit risk exposure. This suggests (surprisingly) that, other things equal, higher regulatory capital requirements on banks to dissuade dollarization may have the opposite effect.

\section{Balancing Risks through Duration, Currency, and Jurisdiction}

The previous discussion raises the obvious question of how coping mechanisms are used in practice to deal with systemic risk. We address that question in this section. We first illustrate that there are risk-balancing effects among the three coping mechanisms in a manner that is consistent with a sort of "conservation principle." ${ }^{25}$ That is, we assume that there is a given level of systemic risk tolerance among investors, so that a reduction in risk exposure via the use of one coping mechanism makes room for investors to increase risk exposure elsewhere. We then show that the typical equilibrium outcome is in fact one in which credit risk exposure is preferred over price risk exposure as systemic risks increase.

\subsection{Risk Balancing}

In this subsection we provide evidence on pair-wise interactions between duration, currency, and jurisdiction. The framework that we use is one according to which investors have a certain level of risk appetite; therefore they can switch between coping mechanisms while keeping the desired level of risk.

Consider first the interaction between duration and currency, for a given jurisdiction. One would expect that, for a given level of risk tolerance, there is a tradeoff between duration and currency of financial contracting, holding jurisdiction constant (which is equivalent to controlling for the level of institutional quality). In particular, an increase in financial dollarization reduces exposure to real interest rate (inflation) risk. This should make investors willing to increase exposure to risks associated with longerdurations. The prediction would hence be that dollar contracts would be of longer duration than peso contracts in the same emerging market jurisdiction.

The evidence suggests that dollarization is indeed associated with longer average duration of financial contracts, for a given jurisdiction. We rely on three pieces of evidence, using maturity as a proxy for duration because of data limitations. First, as illustrated in Figure 1, the average maturity of domestic dollar denominated bonds is substantially longer than that of domestic bonds denominated in pesos. For the case of Argentina the average maturity of peso denominated corporate bonds is around two years, while it is around seven years for dollar denominated ones. In Peru, the difference is smaller (around 3 years) but still goes in the same direction. Secondly, as illustrated in Figure 2, time deposits are more dollarized than sight deposits in the same jurisdiction, with time deposits being of course of longer average maturity than sight deposits. In Argentina, for example, while only eight percent of sight deposits are in dollars, 79

\footnotetext{
${ }^{25}$ We owe this terminology to comments provided by Ricardo Caballero.
} 
percent of time deposits are dollar denominated. In Costa Rica and Ecuador the fraction of dollar time deposits more than doubles that of dollar sight deposits. To be sure, the lesser dollarization of (short-duration) sight deposits may reflect other factors, such as liquidity and transactional needs. Therefore, we present a third piece of evidence in Figure 3. It shows that after Ecuador formally adopted dollarization, in March 2000, the maturity structure of domestic time deposits lengthened. For example, at the end-1999, 19 percent of time deposits were of original maturity of between 90 and 360 days, and this proportion rose significantly after formal dollarization to 48 percent by June $2002{ }^{26}$

Consider now the interaction between jurisdiction and duration, for a given currency. One would expect that a shift to the foreign jurisdiction would enable investors to accept an increase in exposure to long-duration contracts, which, other things equal, are riskier than short-duration contracts. The reason is that this shift would reduce overall risk for investors - for example, by improving contract enforcement, transparency, and market infrastructure. And for a given level of risk appetite, such a reduction would make room for investors to increase duration risk. ${ }^{27}$ This prediction is borne out in Figures 4 and 5, which show that dollar denominated corporate and sovereign bonds that are issued in international markets have a longer average maturity than dollar bonds issued at home. The figures show data for Argentina, Peru, and Uruguay. In all cases, the average maturity is longer in the international market. Figure 6, reproduced from a paper by Schmukler and Vesperoni (2003), shows a similar pattern. The figure shows that after accessing international capital markets, firms from emerging economies increase their dollar long-term debt over equity and reduce the average proportion of dollar short-term debt in total dollar debt.

Finally, consider the interaction between jurisdiction and dollarization, for a given duration of financial contracts. Following the same reasoning as above, it might appear that a risk-reducing move to the foreign jurisdiction should be matched by a willingness to increase exposure to nominal volatility. That is, it might look as if investors should be more willing to hold peso contracts when they are subject to the foreign jurisdiction. The problem with this reasoning is that it fails to recognize that a crucial benefit of shifting to a foreign jurisdiction is a better legal framework to enforce or renegotiate claims in the event of default. As discussed in Section 3.2, this benefit can only be securely seized if contracts are written in dollars because any peso contract, regardless of jurisdiction, can be inflated away. Therefore, taking the litigation option into consideration, one should expect that a shift to a foreign jurisdiction would lead to more dollarization.

\footnotetext{
${ }^{26}$ Note that Figure 3 includes both sucre and dollar deposits in 1999. Therefore, for a given jurisdiction, both the formal dollarization and conversion of existing sucre deposits into dollar deposits had a lengthening effect on the maturity of deposits.

${ }^{27}$ Several papers, such as Cantale (1996), Coffee (2002), Fuerst (1998), Miller and Puthenpurackal (2000), and Reese and Weisbach (2002), explain that by participating in international markets (particularly through cross listing) firms can signal that they are willing to subject themselves to higher disclosure standards and stricter enforcement. By going abroad firms certify to act in the interest of investors.
} 
To illustrate this point, we gather evidence on corporate and sovereign bonds and deposits by currency. Figure 7 shows that for a group of Latin counties the dollar is the currency of denomination of virtually all contracts subject to a foreign jurisdiction, while the proportion of domestic currency debt in domestic markets is typically large. In fact, most cases are extreme ones. For example, corporate bonds from Brazil, Colombia, and Venezuela are 100 percent in domestic currency in domestic markets and 100 percent in foreign currency in international markets. ${ }^{28}$ Other extreme cases are Argentina and Uruguay, countries that almost exclusively issue foreign currency bonds, in domestic and foreign markets. Figure 8 shows a similar picture for sovereign bonds.

Lastly, we present in Figure 9 the evolution of deposits in dollars and pesos after Argentina established the currency board. For this comparison to be relevant, we need to assume that the improvement in institutions under convertibility is tantamount to a shift toward a better jurisdiction. The caveat here is that dollarization may have increased also because of reasons other than the institutional improvement. ${ }^{29}$ This caveat notwithstanding, one can see the effects of a regime change in Figure 9, which shows that after Argentina adopted the currency board, dollarization increased steadily. The share of dollar total deposits went from 47 percent in the year before convertibility, when inflation was very high, to around 74 percent in 2001. Rising dollarization at home during the life of the Argentine currency board does not, however, necessarily imply higher asset dollarization overall. Dollarization at home is probably partly explained by capital repatriation and re-intermediation of cash dollars by Argentine residents once they were given the option to deposit dollars in the domestic banking system. This result is consistent with De Nicoló, Ize, and Honohan (2003), who find that dollarization decreases when there are outright prohibitions to dollar deposits. In this case, dollarization increased when dollar deposits were allowed.

\subsection{Equilibrium Outcome}

In light of the tradeoff between price and price-induced default risk discussed in Section 3, a question that arises naturally is which one of these two risks would emerging markets choose to be exposed to in equilibrium. In Section 3.3 we hypothesized that, as systemic risks rise, the market equilibrium would settle in favor of hedging against price risk at the expense of exposure to price-induced default risk. We submitted the value of the litigation option of a claim as an independent reason that can help explain this equilibrium outcome. Here we show that the equilibrium outcome is in fact consistent with cross-country data and with country-specific time series data.

Table 2 depicts the distribution of peso and dollar deposits among sight, savings, and term accounts in selected, partially dollarized Latin American countries subject to high systemic risk. The table shows that most deposits are in dollars or in short-term

\footnotetext{
${ }^{28}$ In Brazil, the domestic debt is in reais, although a large share of it is in dollar-linked reais.

${ }^{29}$ For a further discussion on the effects of the currency board on dollarization, including the shift in incentives, see de la Torre, Levy Yeyati, and Schmukler (2003).
} 
(sight deposits or passbook savings) pesos_-both of which hedge price risk-instead of in long-duration pesos-which would hedge price-induced default risk. Term deposits in local currency represent only a small proportion of all deposits, accounting on average for about 11 percent of total deposits in the five countries considered, never being larger than 19 percent. A similar picture arises for corporate bonds, as illustrated in Figure 10, which displays the distribution of domestically issued corporate bonds by currency and maturity for Argentina and Peru. The figure shows that the proportion of domestic long-term bonds in pesos is small, while the shares of dollar denominated and short-term (up to five years) bonds are much larger. All this evidence suggests that investors in emerging markets, where systemic risks are high, choose to seek protection against price volatility and dilution risk, thereby preferring to expose themselves to price-induced credit risk.

The evidence above is confirmed by another type of data presented in Figure 11. The top panel of that figure uses a sample of ten developed countries and 47 developing countries. It shows that bank deposit dollarization is substantially larger in developing countries (32 percent compared to eight percent in developed countries) relative to their degree of trade openness. In fact, on average, developing countries are much less open to trade than developed countries, but are much more financially dollarized, suggesting that the high degree of dollarization in developing countries is not explained by trade factors. Moreover, the deposit dollarization in emerging countries significantly underestimates their total liability dollarization, as their bonded corporate and sovereign debt is, as noted earlier, highly dollarized. This suggests that dollarization is more widespread in environments with larger systemic risks, implying an equilibrium outcome that favors exposure to credit risk over exposure to price risk.

Time series data for individual countries also provide evidence on the equilibrium outcome. This is strikingly illustrated in the bottom panel of Figure 11, which depicts changes in the composition of Brazil's domestic federal debt since 1996. The clear message of this figure is that, as perceptions of systemic risk rise (as measured, for example, by the EMBI spreads on Brazilian sovereign debt), the market equilibrium shifts in favor of short-duration local currency debt and dollar-linked debt. In effect, following the East Asian crisis, the share of longer-duration (fixed interest rate) debt collapsed while the shares of dollar-linked debt and, in particular, short-duration debt (i.e., debt indexed to the overnight interest rate - the Selic) rose appreciably. Similarly, in the period leading to the most recent elections, when investor jitters pushed country risk perceptions to very high levels, the share of longer-duration debt took a nosedive while dollar-linked debt rose substantially. By contrast, as financial tranquility resumed (after the elections), the market was willing to start increasing, from very low levels, its holdings of longer-duration debt. However, the use of Selic-indexed debt remained very high, suggesting that the perception of important systemic risk did not subside completely.

In sum, the equilibrium outcome-i.e., the revealed preference of financial markets to hedge price risk at the expense of exposure to credit risk as systemic risk rises-is well documented by cross-country and time series data. While it is difficult to 
sort out the relative importance of competing explanations for this outcome, the value of the option to litigate given default appears as a potentially appealing candidate.

\section{Final Remarks}

Rather than going over again the main messages of the paper (which are already summarized in the introduction and in Section 3.3), we discuss some implications of our analysis for the current debate on financial dedollarization. We then conclude by identifying areas for future research.

This paper raises important caveats and warnings for the policy debate on financial dedollarization. The bottom line of placing the debate in the more general framework of coping mechanisms is that it is not straightforward to dedollarize an economy without incurring other risks. But this does not imply that dedollarization policy should "throw in the towel." On the one hand, our analysis does caution against an undue focus on the dollarization symptom, arguing that isolated policies and reforms can actually lead to higher dollarization and can result mainly in risk shifting and risk balancing (rather than risk reduction). On the other hand, our analysis can indeed lend support to a multipronged policy approach to dedollarize, provided that such an approach reflects and fosters a broad-based process of institutional and policy upgrading that results in a durable reduction of aggregate systemic risk.

The economics profession seems to be moving toward a consensus on a threepronged dedollarization policy agenda, involving macroeconomic policy (i.e., exchange rate flexibility cum inflation targeting), ${ }^{30}$ prudential policy (e.g., higher capital requirements for dollar loans to debtors in the non-tradable sector) ${ }^{31}$ and financial policy (i.e., the promotion of CPI-indexed contracts, possibly aided by CPI-indexed lending and borrowing by multilateral organizations). ${ }^{32}$ Consistent steps on all three fronts that reflect and promote durable institutional upgrading could in principle reduce financial dollarization without materially increasing other risks. In fact, it follows clearly from the analysis in this paper that inflation targeting cum exchange rate flexibility can foster longer-duration peso contracting to the extent that it lowers the variance of inflation relative to that of the real exchange rate. Also, prudential norms could complement this process by increasing the cost of lending in dollars to non-dollar earners. Furthermore, long-duration contracts denominated in CPI-indexed units can provide a tradeoff-free hedging option - one that can reasonably shield the investor against price and dilution risks without raising her exposure to price-induced default risk. Moreover, by lending to emerging countries in their CPI-indexed units (and matching such activity with samedenomination borrowings), multilateral organizations can share their de-facto preferred creditor status with private agents, boosting the attractiveness of CPI-indexed contracts.

\footnotetext{
${ }^{30}$ See, for example, Goldstein (2002), Ize and Parrado (2002), and IMF (2003).

${ }^{31}$ See, for example, IMF (2003) and Latin American Shadow Financial Regulatory Committee, Declaration No. 9, September 15, 2003.

32 In fact, the Board of the World Bank has already approved lending in local currency but only a few operations have taken place. For a discussion on this type of lending, see Levy Yeyati (2003b).
} 
Our analytical framework, however, balances this potentially positive outlook on financial dedollarization policies with a strong sense of the complexities involved. It not only makes the basic argument that these policies would succeed only to the extent that they result in, or are accompanied by, a permanent reduction in overall systemic risk. It also points to the difficult thresholds that must be crossed for each of the three policy prongs to chip away financial dollarization in a sustainable manner. In effect, without resilient fiscal viability (the absence of "fiscal dominance"), exchange rate flexibility cum inflation targeting would not be able to lead to a durable milieu with a low inflation rate that is consistently less volatile than the real exchange rate. This requires, among other things, a major strengthening in both fiscal and monetary institutions. Moreover, the initial level of financial dollarization matters significantly. It leads to "fear of floating." This is not the fear that flexibility in the nominal exchange rate would affect the path of the equilibrium real exchange rate (such path is largely invariant to the monetary and exchange rate regime). It is the fear that flexibility would result in "excess" exchange rate fluctuations (above and beyond what is needed to aid in the adjustment in the real exchange rate toward its new, more depreciated equilibrium level), which would be more damaging (measured by "excess" non-performing loans and defaults) the higher the initial degree of financial dollarization.

The problems inherent in the prudential policy prong are also not trivial. In particular, increasing regulatory capital requirements for dollar loans to the non-tradable sector raises the basic question of why not also increasing capital requirements for shortduration peso loans. After all, as argued in this paper, both types of loans entail the tradeoff of exposing the lender to price-induced default risk-i.e., default induced by an unexpected surge in the real exchange rate or real interest rate, respectively. A shift from dollar loans to short-term peso loans may be the sequel of increasing capital requirements for only dollar loans to non-dollar earners. Moreover, raising capital requirements at home could lead to a migration of dollar contracting to the seedy variety of offshore jurisdictions-which entail greater information opacity and inadequate prudential oversight. Such requirements would also make it more difficult for banks to avoid duration and/or currency mismatches in their own balance sheets, unless they simply shrink. Furthermore, it is not clear which of the two price-induced default risks is less insidious - historically, duration mismatches in balance sheets appear to have been as frequent and important a determinant of banking crises as currency mismatches.

The proposals to promote CPI-indexed peso contracts also need to overcome high hurdles to become effective. First, such contracts may not "stick" in an environment with a high and highly volatile real interest rate. The surge in real interest rates appears to have been the main reason for the failed attempt to introduce CPI-indexed contracts in Ecuador during the mid-1990s. It also seems to have been the main factor behind the progressive disfiguration of the indexing formula in Colombia during the 1990s. These country experiences illustrate that volatile real interest rates introduce a difficult-to-resist incentive for frequent adjustments in the (real) interest rate charged on CPI-indexed contracts, 
which reduce their duration, thereby re-introducing the tradeoff between price and default risk that they were initially intended to eliminate. ${ }^{33}$

Second, the introduction of CPI-indexed contracts may be difficult when inflation is already low (as is currently the case of most Latin countries). Third, these contracts are not fully protected from dilution risk - the index is unavoidably backward looking-and are exposed to confiscation risk-for example, the government can tamper with the indexing formula. And fourth, the scope for involvement of multilateral organizations appears limited. While residents (including pension funds) in the emerging market may be induced to take CPI-indexed instruments, foreign investors may be uninterested in them, especially in the case of the less developed and smaller emerging countries-i.e., the countries that are more likely to be dollarized and, hence, in greater need of the dedollarization "cure." ${ }^{34}$ In such cases, multilateral organizations would have to borrow in CPI-indexed units mainly from residents (e.g., pension funds), rather than from foreign investors, which may still foster the development of a domestic market for CPI-indexed contracts but without providing additional external financing to the emerging country in question.

To conclude, this paper opens areas for future research in various directions. One possible direction is to expand the sets of items under analysis. While the paper has focused on savings/lending contracts, it would be interesting to examine other contracts, such as insurance contracts, which imply liability risk for the issuer, and equity contracts, which are by nature non-fixed income and whose dividends are tied to the company's performance. Similarly, the paper has chosen a relatively small subset of systemic risks affecting life in emerging markets. There are, however, many other relevant risks that could be studied, including, importantly, liquidity and rollover risks. By the same token, the analysis could be expanded to a larger set of coping mechanisms, including, as noted earlier, over-reliance on real estate collateral and loans to related parties.

Future research could also take the direction of probing more deeply into some of the puzzling issues raised here. This could be done via formal modeling or empirical work. It would be useful, for example, to better ascertain how important is the litigation option of a claim (relative to other factors) in determining the prevalence of exposure to credit risk in equilibrium. Also, it would be important to better characterize whether the heavy use of coping mechanisms is the reflection of underinsurance or constrained optimization. Finally, there is a need to identify more clearly which thresholds need to be overcome in terms of institutional improvement in order for duration, dollarization, and jurisdiction to become more of an opportunity (rather than a refuge) for financial contracting in emerging markets.

\footnotetext{
${ }^{33}$ In Colombia, the reemergence of this tradeoff-as the unit was re-indexed to the nominal (deposit) interest rate (rather than to the CPI) during the 1990s-resulted in substantial duration mismatches among mortgage debtors. This led to massive decay in the mortgage loan portfolio and a major crisis in the savings and loans (S\&L) sector when the real interest rate spiked in 1998-99, in the aftermath of the Russia crisis.

${ }^{34}$ For evidence on the role of domestic and foreign investors on dollarization, see Claessens, Klingebiel, and Schmukler (2003).
} 


\section{References}

Atje, R., and Jovanovic, B., 1993, "Stock Markets and Development," European Economic Review, 37:2-3, pp. 632-640.

Bagehot, W., 1873, Lombard Street, Homewood, IL: Richard D. Irwin (1962 Edition).

Bekaert, G., Harvey, C., and Lundblad, C., 2001, "Does Financial Liberalization Spur Growth?," mimeo, Columbia Business School, Duke University, and Indiana University, April.

Beck, T., and Levine, R., 2002, "Stock Markets, Banks, and Growth: Panel Evidence," NBER Working Paper 9082, July.

Blanchard, O., and Missale, A., 1994, "The Debt Burden and Debt Maturity," American Economic Review, 84:1, pp. 309-319.

Broda, C., and Levy Yeyati, E., 2001, "Dollarization and the Lender of Last Resort," in E. Levy Yeyati and F. Sturzenegger (eds.), Dollarization: Debates and Policy Alternatives, MIT Press, 2003.

Broner, F., Lorenzoni, G., and Schmukler, S., 2003, "Why Do Emerging Markets Borrow Short Term?" mimeo, University of Maryland, Princeton University, and World Bank.

Burnside, C., Eichenbaum, M. and Rebelo, S., 2001, "Hedging and Financial Fragility in Fixed Exchange Rate Regimes," European Economic Review, 45, pp.1151-93.

Caballero, R., and Krishnamurthy A., 1998, "Emerging Market Crises: An Asset Markets Perspective," NBER Working Paper 6843.

Caballero, R., and Krishnamurthy A., 2003, "Excessive Dollar Debt: Financial Development and Underinsurance," Journal of Finance, 58:2, pp. 867-893.

Calvo, G., 1988, "Servicing the Public Debt: The Role of Expectations," American Economic Review, 78:4, pp. 647-661.

Calvo, G., 1995, "Varieties of Capital Market Crises," Working Paper 15, Center for International Economics, University of Maryland.

Calvo, G., 1998, "Capital Flows and Capital Market Crises: The Simple Economics of Sudden-Stops," Journal of Applied Economics, CEMA, Argentina, 1:1, pp. 35-54.

Calvo, G., and Mendoza, E., 1996, "Mexico's Balance-of-Payments Crisis: A Chronicle of a Death Foretold," Journal of International Economics, 41, 235-264.

Calvo, G., and Mishkin, F., 2003, "The Mirage of Exchange Rate Regimes for Emerging Market Countries," NBER Working Paper 9808, June.

Calvo, G., and Reinhart, C., 2000, "When Capital Flows Come to a Sudden Stop: Consequences and Policy,” in P. K. Kenen and A. K. Swoboda (eds.), Key Issues in Reform of the International Monetary and Financial System, Washington D.C.: International Monetary Fund.

Calvo, G., Izquierdo, A., and Talvi, E., 2003, "Sudden Stops, the Real Exchange Rate, and Fiscal Sustainability: Argentina's Lessons," NBER Working Paper 9828, July.

Cantale, S., 1996, "The Choice of a Foreign Market as a Signal," INSEAD Working Paper.

Caprio, G., and Hanson, J., 2001, "The Case for Liberalization and Some Drawbacks," in G. Caprio, P. Honohan, and J. Stiglitz (eds.), Financial Liberalization: How Far, How Fast? Cambridge University Press. 
Chang, R. and Velasco, A., 2000, "Liquidity Crises in Emerging Markets: Theory and Policy," in B. Bernanke and J. Rotemberg (eds.), NBER Macroeconomics Annual 1999, Cambridge: The MIT Press, 2000.

Chang, R., and Velasco, A., 2001, "A Model of Financial Crises in Emerging Markets," The Quarterly Journal of Economics, 116:2, 489-517.

Chang, R., and Velasco, A., 2003, "Endogenous Dollarization and Monetary Policy," presented at the IADB/World Bank conference "Financial Dedollarization: Policy Options," December 1-2, 2003.

Claessens, S., Klingebiel, D., and Schmukler, S., 2003, "Government Bonds in Domestic and Foreign Currency: The Role of Macroeconomic and Institutional Factors," CEPR Working Paper No. 3789.

Coffee, J.C. Jr., 2002, "Racing Towards the Top?: The Impact of Cross-Listings and Stock Market Competition on International Corporate Governance," Columbia Law and Economics Working Paper 205, May.

De Ferranti, D., Perry, G., Gill, I., and Servén, L., 2000, Securing Our Future in a Global Economy, World Bank Latin American and Caribbean Studies.

De la Torre, A., Levy Yeyati, E., and Schmukler, S., 2002, "Financial Globalization: Unequal Blessings," International Finance, 5:3, pp. 335-357.

De la Torre, A., Levy Yeyati, E., and Schmukler, S., 2003, "Living and Dying with Hard Pegs: The Rise and Fall of Argentina's Currency Board," Economia, Spring, pp. 43107.

De Nicoló, G., Honohan, P., and Ize, A., 2003, "Dollarization of the Banking System: Good or Bad?," World Bank Policy Research Working Paper 3116.

Demirgüç-Kunt, A., and Detragiache, E., 2001, "Financial Liberalization and Financial Fragility," in G. Caprio, P. Honohan, and J. Stiglitz (eds.), Financial Liberalization: How Far, How Fast? Cambridge University Press.

Demirguc-Kunt, A., and Maksimovic, V., 1998, "Law, Finance, and Firm Growth," Journal of Finance, 53:6, pp. 2107-2137.

Dooley, M., 2000, "A Model of Crises in Emerging Markets," The Economic Journal, 110: 460, pp. 256-272.

Eichengreen, B., and Hausmann, R., 1999, "Exchange Rates and Financial Fragility," NBER Working Paper 7418.

Eichengreen, B., Hausmann, R., and Panizza, U., 2003, "The Mystery of Original Sin," in B. Eichengreen and R. Hausmann (eds.), Debt Denomination and Financial Instability in Emerging Market Economics, forthcoming.

Frankel, J., and Rose, A., 1996, "Currency Crashes in Emerging Markets: Empirical Indicators," Journal of International Economics, 41:3-4, 351-367.

Fuerst, O., 1998, "A Theoretical Analysis of the Investor Protection Regulations Argument for Global Listing of Stocks," mimeo, Yale School of Management.

Furman, J., and Stiglitz, J., 1998, "Economic Crises: Evidence and Insights from East Asia," Brookings Papers on Economic Activity, 2, 1-114.

Goldstein, M., 2002, "Managed Floating Plus," Institute for International Economics.

Hausmann, R., 2001, "A Way Out for Argentina: The Currency Board Cannot Survive Much Longer," Financial Times, October 30. 
Hausmann, R., Gavin, M., Pages-Serra, C., and Stein, E., 1999, "Financial Turmoil and the Choice of Exchange Rate Regime," IADB Working Paper 400.

Henry, P. B., 2000, "Stock Market Liberalization, Economic Reform, and Emerging Market Equity Prices," Journal of Finance, 55:2, pp. 529-564.

Honohan, P., and Shi, A., 2002, "Deposit Dollarization and the Financial Sector in Emerging Economies," World Bank Working Paper 2748, January.

Inter-American Development Bank, 1995, Overcoming Volatility, Report on Economic and Social Progress in Latin America.

International Monetary Fund, 2003, "Financial Stability in Dollarized Economies," Occasional Paper, forthcoming.

Ize, A., and Levy Yeyati, E., 2003, "Financial Dollarization," Journal of International Economics, 59, pp. 323-347.

Ize, A., and Parrado, E., 2002, "Dollarization, Monetary Policy, and the Pass-Through," IMF Working Paper 02/188, November.

Jayaratne, J., and Strahan, P., 1996, "The Finance-Growth Nexus: Evidence from Bank Branch Deregulation," Quarterly Journal of Economics, 111:3, pp. 639-670.

Jeanne, O., 2000, "Debt Maturity and the Global Financial Architecture," European Economic Review, 44: 4-6, pp. 719-727.

Kaminsky, G., and Schmukler, S., 2002, "Short-Run Pain, Long-run Gain: The Effects of Financial Liberalization," World Bank Working Paper 2912.

King, R. G., and Levine, R., 1993, "Finance and Growth: Schumpeter Might Be Right," Quarterly Journal of Economics, 108:3, pp. 717-37.

La Porta, R., Lopez-de-Silanes, F., and Shleifer, A., 2000, "Government Ownership of Banks," Journal of Finance, 57:1, pp. 265-301.

La Porta, R., Lopez-de-Silanes, F., and Shleifer, A., 2002, "What Works in Securities Laws?" mimeo, Harvard University, October.

La Porta, R., Lopez-de-Silanes, F., Shleifer, A., and Vishny, R. W., 1997, “Legal Determinants of External Finance,', Journal of Finance, 52, pp. 1131-50.

Levine, R., 2001, "International Financial Liberalization and Economic Growth," Review of International Economics, 9:4, pp. 684-698.

Levine, R., Loayza, N., and Beck, T., 2000, "Financial Intermediation and Growth: Causality and Causes," Journal of Monetary Economics, 46:1, pp. 31-77.

Levine, R., and Zervos, S., 1998, "Stock Markets, Banks, and Economic Growth," American Economic Review, 88:3, pp. 537-558.

Levy Yeyati, E., 2003a, "Financial Dollarization: Where Do We Stand?," presented at the IADB/World Bank conference "Financial Dedollarization: Policy Options," December 1-2, 2003.

Levy Yeyati, E., 2003b, "Financial Dedollarization and the Role of the IFIs: Dedollarizing Multilateral Credit," mimeo, Universidad T. Di Tella.

McKinnon, R., and Pill, H., 1998, "International Overborrowing: A Decomposition of Credit and Currency Risks," World Development, 7, pp.1267-82.

Miller, D., and Puthenpurackal, J., 2000, "The Costs, Determinants, and Wealth Effects of Public Yankee Bond Offerings," The Journal of Financial Intermediation, forthcoming. 
Mishkin, F., and Savastano, M., 2001, "Monetary Policy Strategies for Latin America," Journal of Development Economics, 66:2, pp. 415-444.

Rajan, R., and Zingales, L., 2003, Saving Capitalism from the Capitalists, New York: Crown Business Division of Random House.

Rajan, R., and Zingales, L., 1998, "Financial Dependence and Growth," American Economic Review, 88:3, pp. 559-586.

Reese, W. A. Jr., and Weisbach, M. S., 2002, "Protection of Minority Shareholder Interests, Cross-Listing in the United States, and Subsequent Equity Offerings," Journal of Financial Economics, 66:1, pp. 65-104.

Rodrik, D., and Velasco, A., 1999, "Short-Term Capital Flows," in Annual World Bank Conference on Development Economics, Washington, D.C.: World Bank.

Sachs J., Tornell, A., and Velasco, A., 1996, "Financial Crises in Emerging Markets: The Lessons from 1995," Brookings Paper on Economic Activity, 1, 147-215.

Schmukler, S. and Vesperoni, E., 2003, "Financial Globalization and Debt Maturity in Emerging Economies," IMF Working Paper 01/95.

Schneider, M., and Tornell, A., 2001, "Bailout Guarantees, Balance Sheet Effects, and Financial Crises," Review of Economic Studies, forthcoming.

Schumpeter, J. A., 1912, “Theorie der Wirtschaftlichen Entwicklung," Leipzig: Dunker \& Humblot [The Theory of Economic Development 1912, translated by Redvers Opie. Cambridge, MA: Harvard University Press, 1934.]

Tirole, J., 2002, Financial Crises, Liquidity, and the International Monetary System, Princeton: Princeton University Press. 
Table 1

Emerging Market Systemic Risks and Coping Mechanisms

(From the Viewpoint of the Lender)

\begin{tabular}{l|c|c|c}
\hline Risks & Duration & Currency & Jurisdiction \\
\hline $\begin{array}{l}\text { 1. Price risk (relative volatility) } \\
\text { Real interest rate (inflation) } \\
\text { Real exchange rate }\end{array}$ & $\sqrt{ }$ (short) & $\sqrt{ }$ (dollar) & \\
$\sqrt{ }$ (peso) & \\
$\begin{array}{l}\text { 2. Probability of default } \\
\text { Real interest rate induced } \\
\text { Real exchange rate induced }\end{array}$ & $\sqrt{ }$ (long) & $\sqrt{ }($ dollar) & \\
$\sqrt{ }$ (peso) & $\sqrt{ }$ & \\
3. Loss given default & & $\sqrt{ }$ (follar) & \\
4. Dual agency & & $\sqrt{ }$ (dollar) & \\
$\quad \begin{array}{l}\text { Dilution (price) } \\
\text { Confiscation (default) }\end{array}$ & & & $\sqrt{ }$ (foreign) \\
\hline
\end{tabular}

The table summarizes the risk-coping roles of duration, currency, and jurisdiction in contracts involving emerging economy assets. 
Table 2

Distribution of Bank Deposits by Currency and Maturity

Share of Total Deposits

\begin{tabular}{lcccccccc}
\hline & \multicolumn{2}{c}{ Sight deposits } & & \multicolumn{2}{c}{ Savings deposits } & & \multicolumn{2}{c}{ Time deposits } \\
\cline { 2 - 3 } \cline { 7 - 8 } & $\begin{array}{c}\text { Local } \\
\text { Currency }\end{array}$ & $\begin{array}{c}\text { Foreign } \\
\text { Currency }\end{array}$ & & $\begin{array}{c}\text { Local } \\
\text { Currency }\end{array}$ & $\begin{array}{c}\text { Foreign } \\
\text { Currency }\end{array}$ & & $\begin{array}{c}\text { Local } \\
\text { Currency }\end{array}$ & $\begin{array}{c}\text { Foreign } \\
\text { Currency }\end{array}$ \\
\hline Argentina & 14.3 & 1.2 & & 9.8 & 6.7 & & 14.3 & 53.7 \\
Bolivia & 5.6 & 21.5 & & 1.6 & 22.9 & & 0.3 & 48.2 \\
Ecuador & 17.2 & 6.1 & & 16.0 & 13.0 & & 18.6 & 29.1 \\
Peru & 6.7 & 10.8 & & 6.1 & 19.5 & & 16.8 & 40.1 \\
Uruguay & 5.2 & 10.2 & & 1.8 & 12.5 & & 6.1 & 64.2 \\
Average & 9.8 & 10.0 & & 7.0 & 14.9 & & 11.2 & 47.0 \\
\hline
\end{tabular}

The table shows the distribution of bank deposits by currency and maturity in Argentina, Bolivia, Ecuador, Peru, and Uruguay. Figures are as of December 2000 for Argentina and Uruguay, December 2002 for Bolivia and Peru, and January 1999 for Ecuador.

Source: National sources 
Figure 1

Average Maturity of Domestic Corporate Bonds by Currency

In years, 2000

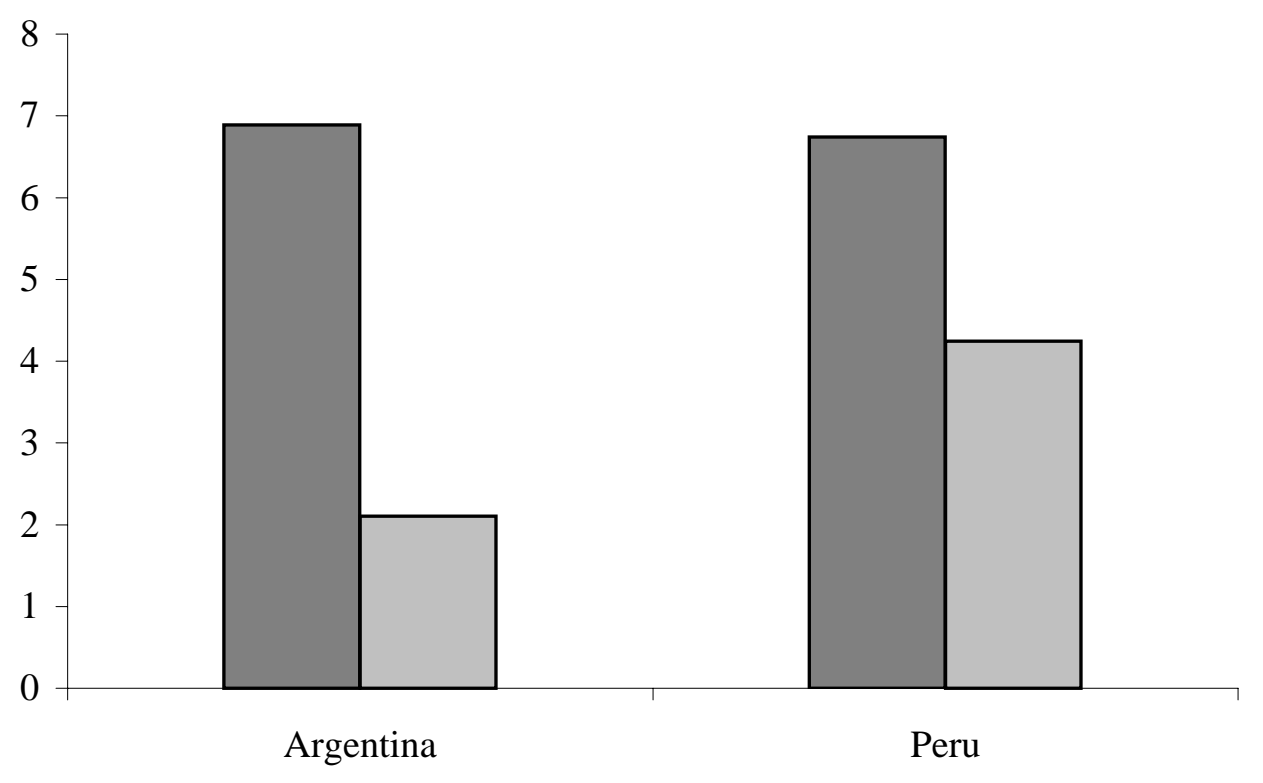

$\square$ Foreign currency bonds $\quad \square$ Domestic currency bonds

The figure displays the average maturity (weighted by amount issued) of Argentine and Peruvian domestic corporate bonds issued in 2000 by currency. Bonds of maturity shorter than one year are excluded from the sample.

Source: Bloomberg 
Figure 2

\section{Bank Deposits by Maturity and Currency}

Argentina (Dec-2000)

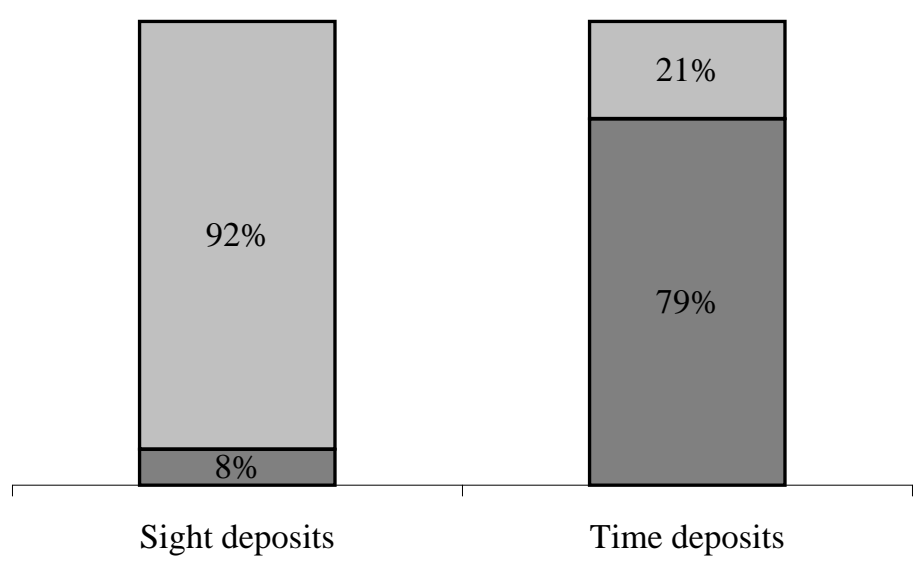

Costa Rica (Dec-2000)

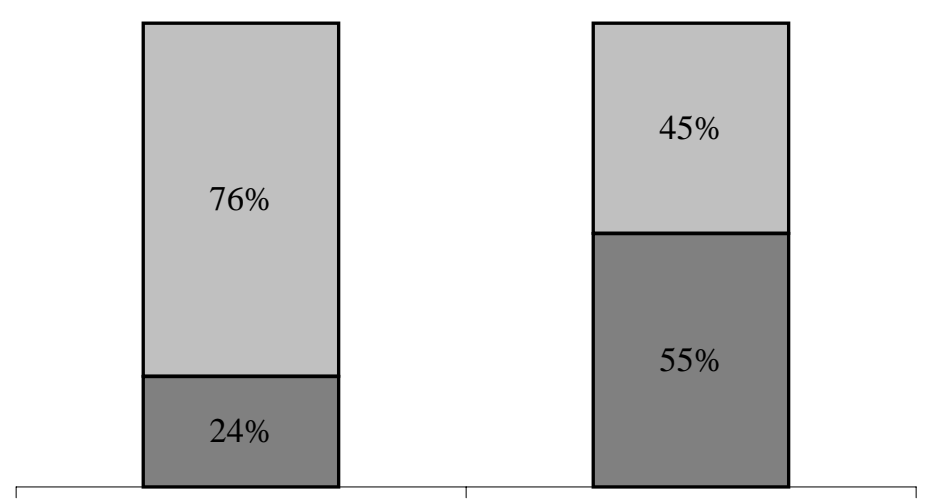

Sight deposits

Time deposits

Peru (Dec-2002)

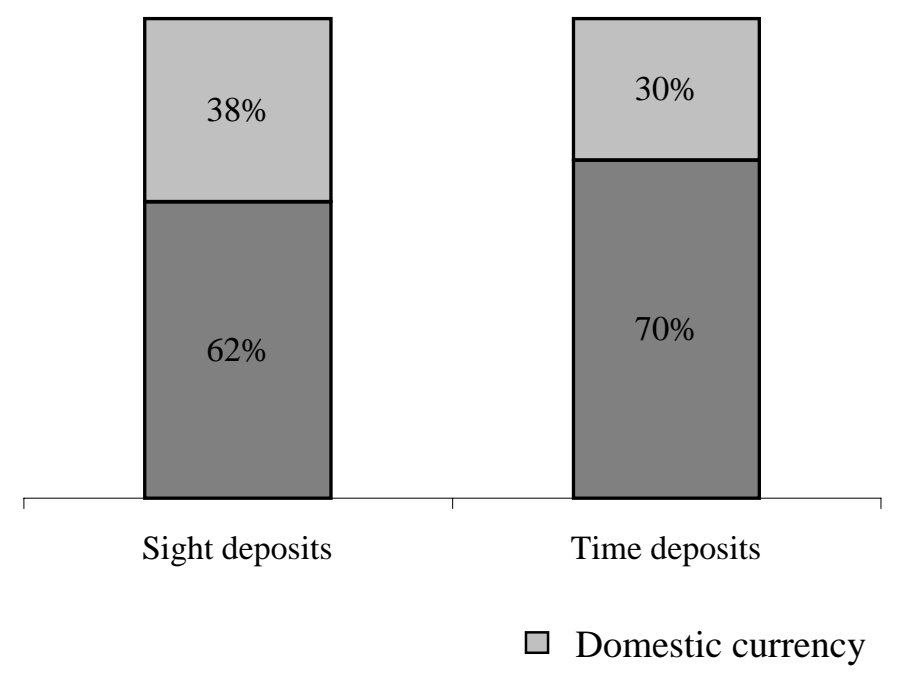

Bolivia (Dec-2002)

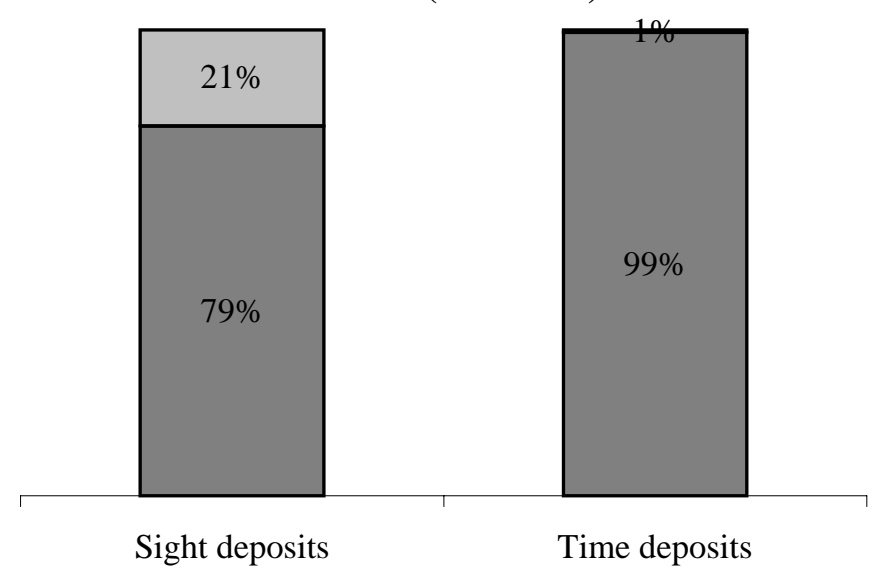

Ecuador (Jan-1999)

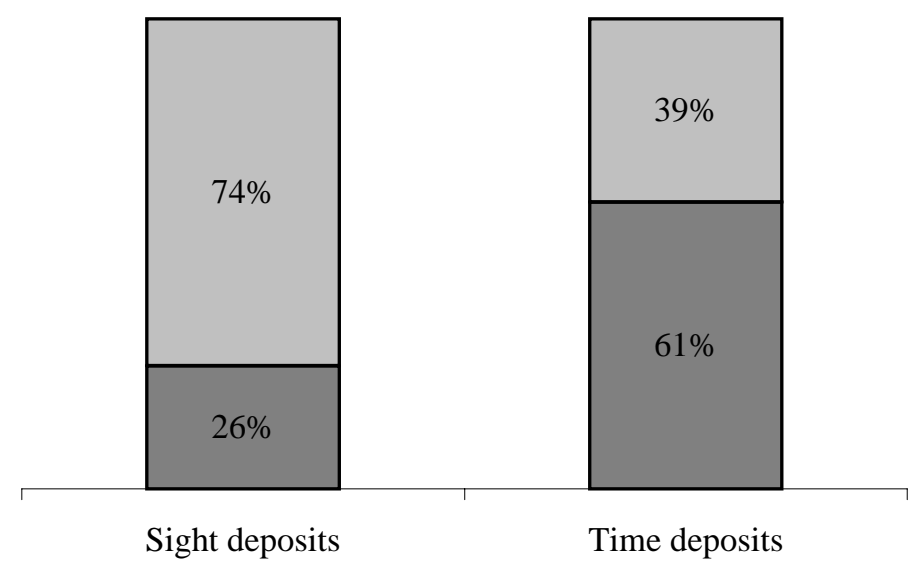

Uruguay (Dec-2000)

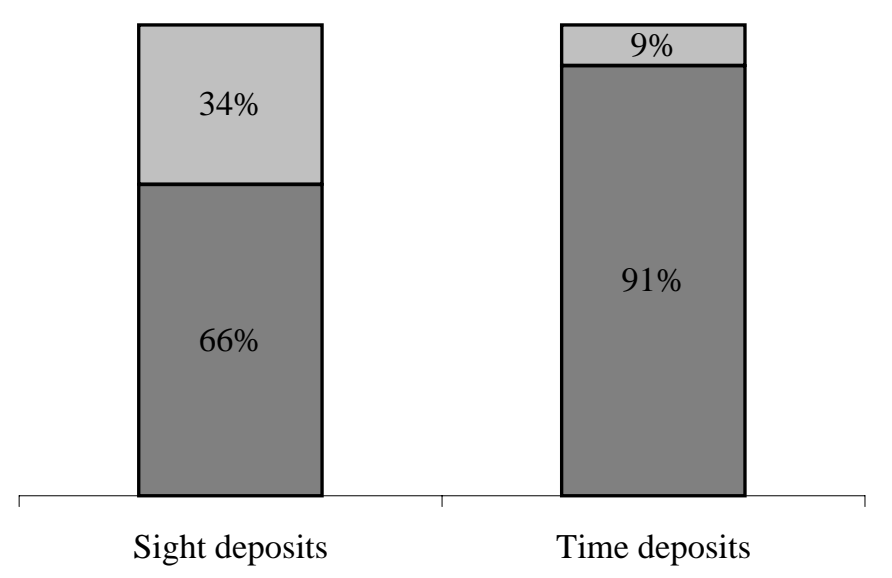

$\square$ Foreign currency

The figures show the distribution of sight and time deposits by currency in Argentina, Bolivia, Costa Rica, Ecuador, Peru, and Uruguay.

Source: National sources 
Figure 3

Dollarization and Maturity of Bank Deposits in Ecuador

Maturity of Time Deposits

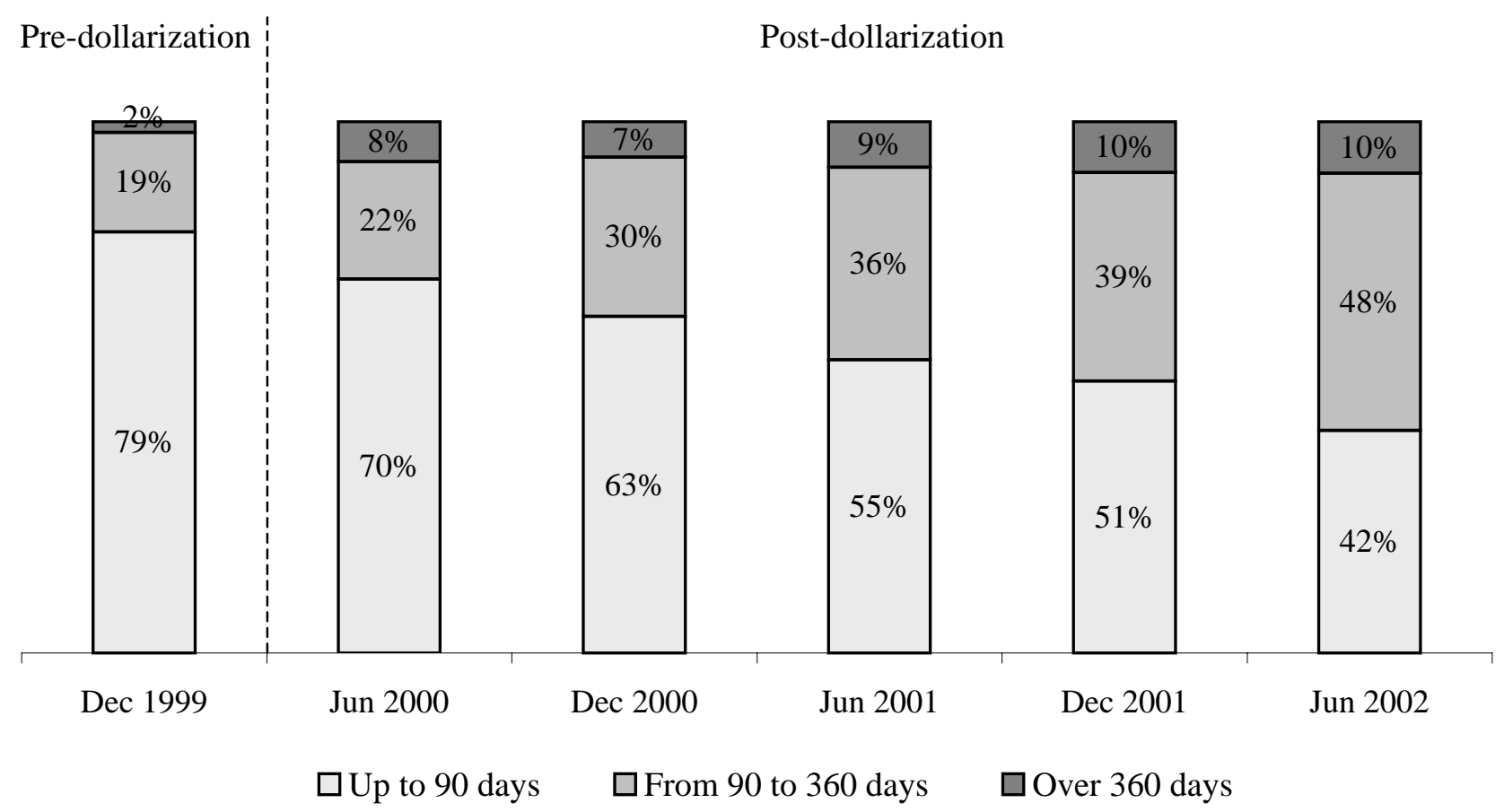

The figure shows the maturity of bank time deposits before and after dollarization in Ecuador. Dollarization was announced by President Mahuad in January 2000, but legally entered into effect only in March 2000. The data do not include banks taken over by AGD ("banca de saneamiento").

Source: Superintendency of Banks of Ecuador 
Figure 4

Average Maturity of Corporate Dollar Bonds by Jurisdiction

In years

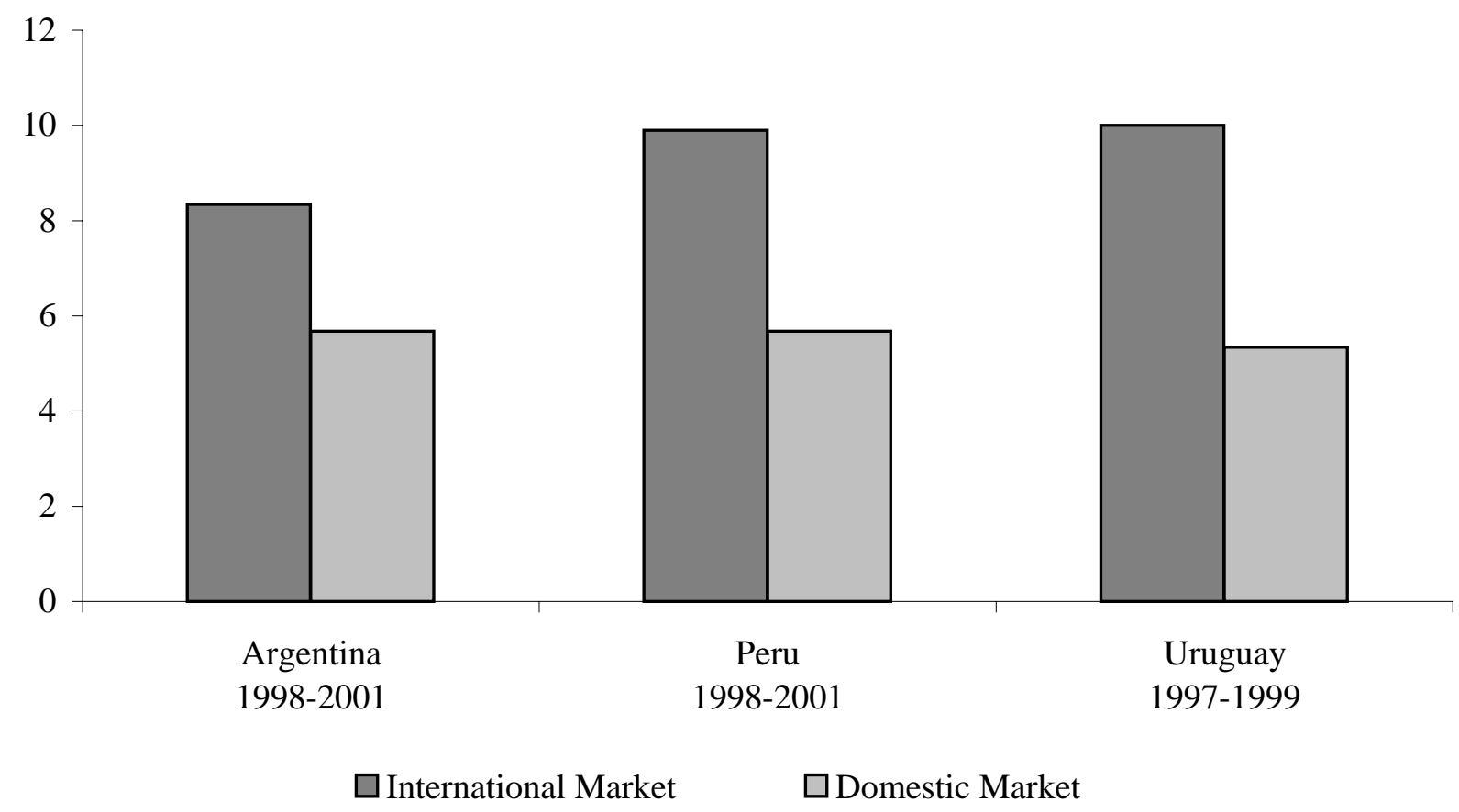

The figure shows the average maturity (weighted by amount issued) of corporate international and domestic bonds denominated in dollars issued by Argentina, Peru, and Uruguay. Bonds of maturity shorter than one year are excluded from the sample. Bonds issued during different periods of time are displayed due to limitations in the availability of data.

Source: Bloomberg 
Figure 5

Average Maturity of Sovereign Dollar Bonds by Jurisdiction

In years

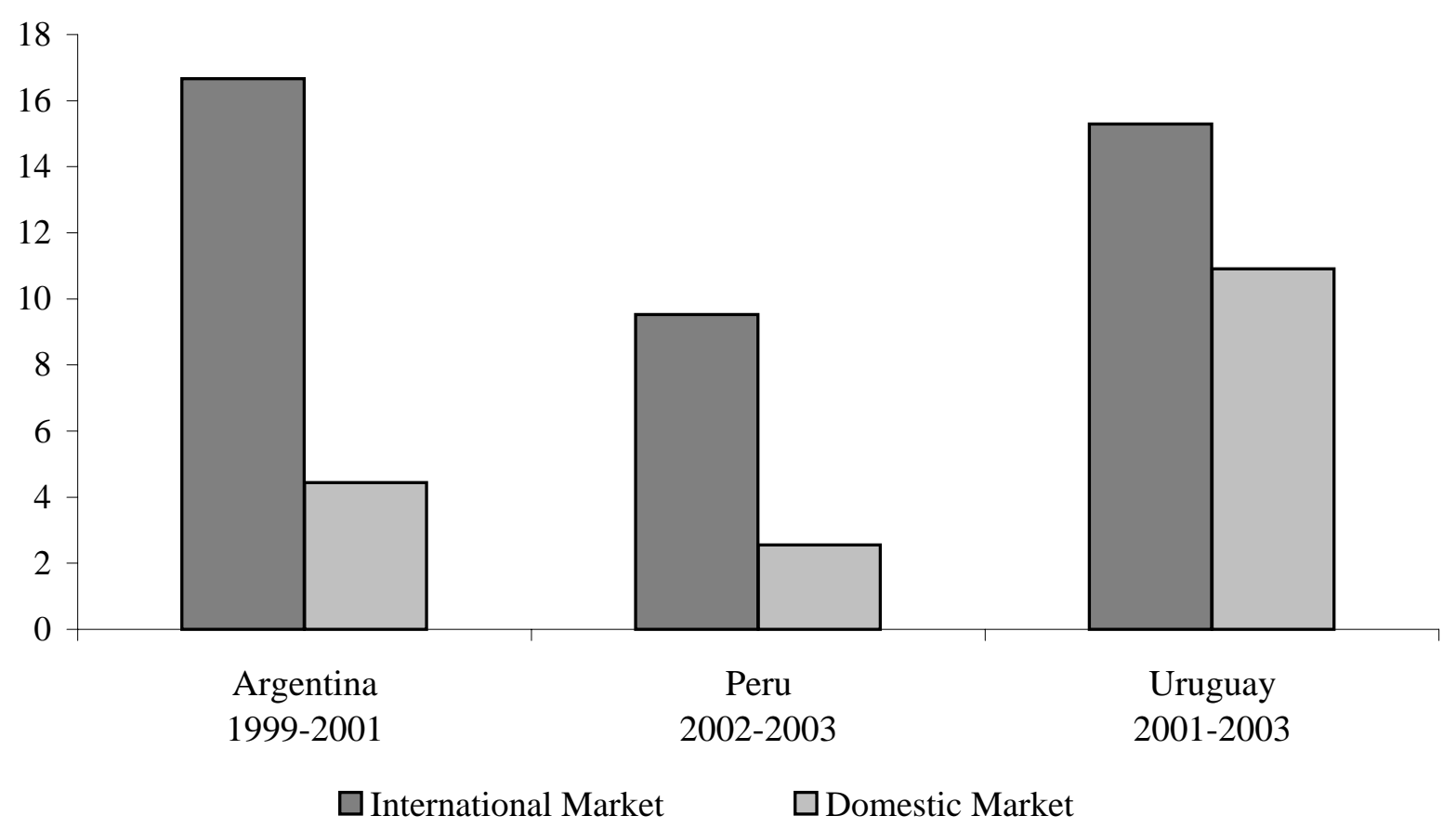

The figures show the average maturity (weighted by amount issued) of sovereign international and domestic bonds denominated in dollars issued by Argentina, Peru, and Uruguay. Bonds of maturity shorter than one year are excluded from the sample. Bonds issued during different periods of time are displayed due to limitations in the availability of data. Source: Bloomberg 
Figure 6

Effects of Financial Liberalization and Access to International Markets

Firms With Access to International Bond Markets

Average of Long-Term Debt over Equity

Average of Short-Term Debt over Total Debt

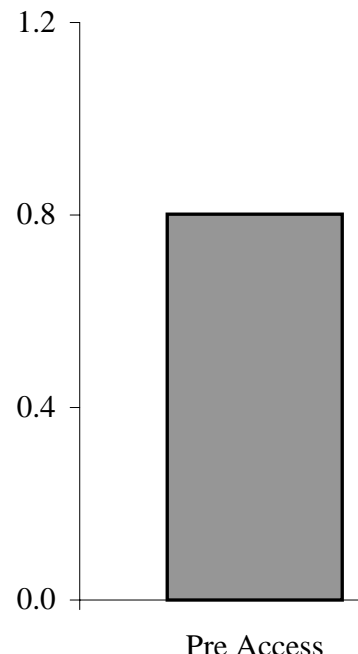

Pre Access

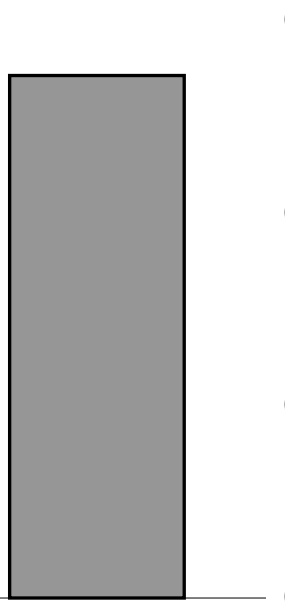

After Access

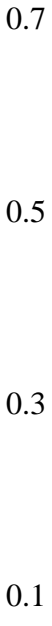

0.1

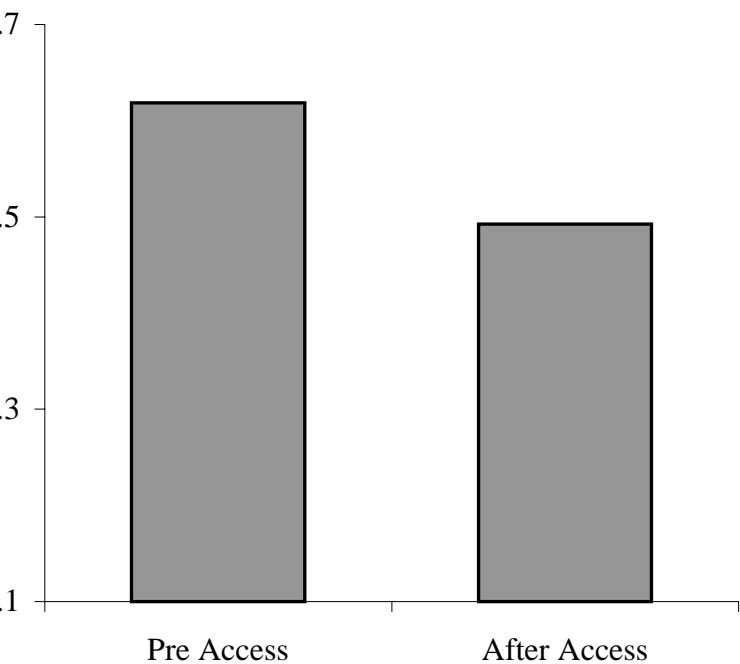

The figures display the average of long-term debt over equity and short-term debt over total debt for international firms (those that access international bond markets at some point during the sample period) before and after they access international markets. The sample of countries includes Argentina, Brazil, Mexico, Indonesia, Malaysia, South Korea, and Thailand.

Source: Schmukler and Vesperoni (2003) 
Figure 7

Dollarization of Corporate Bonds by Jurisdiction

Shares of Amount Issued in Foreign and Domestic Currencies - Maturity of 1-4 Years (2000)

Domestic Market

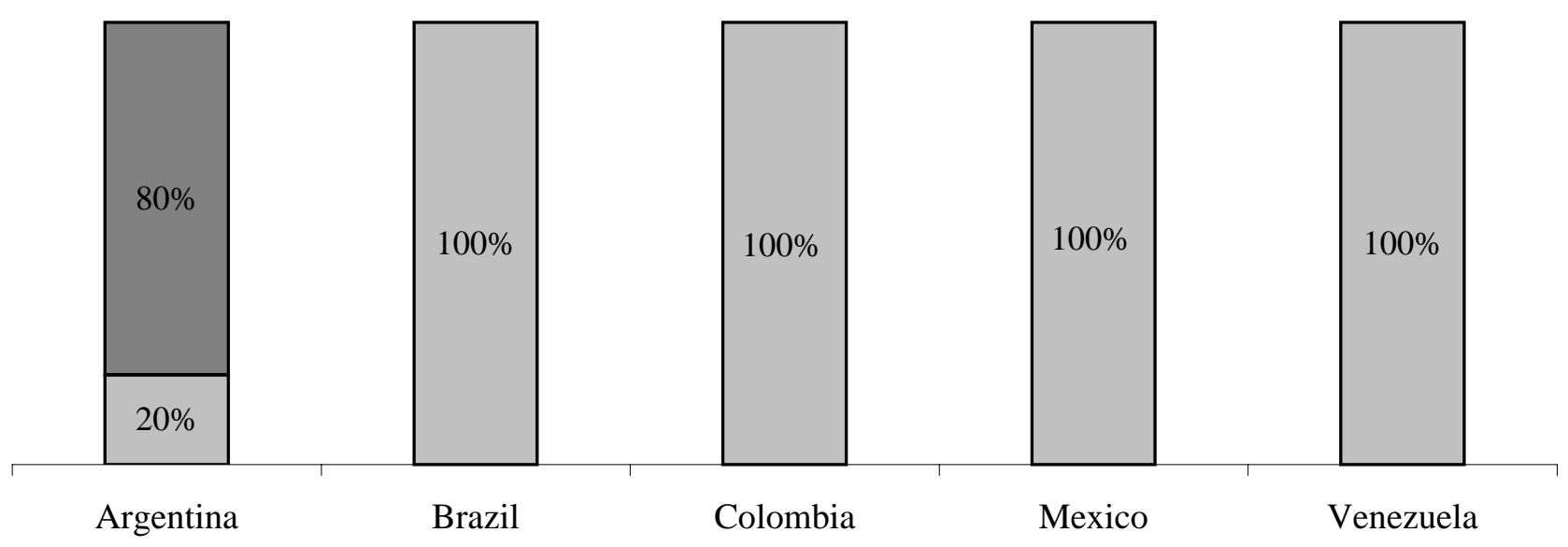

International Market

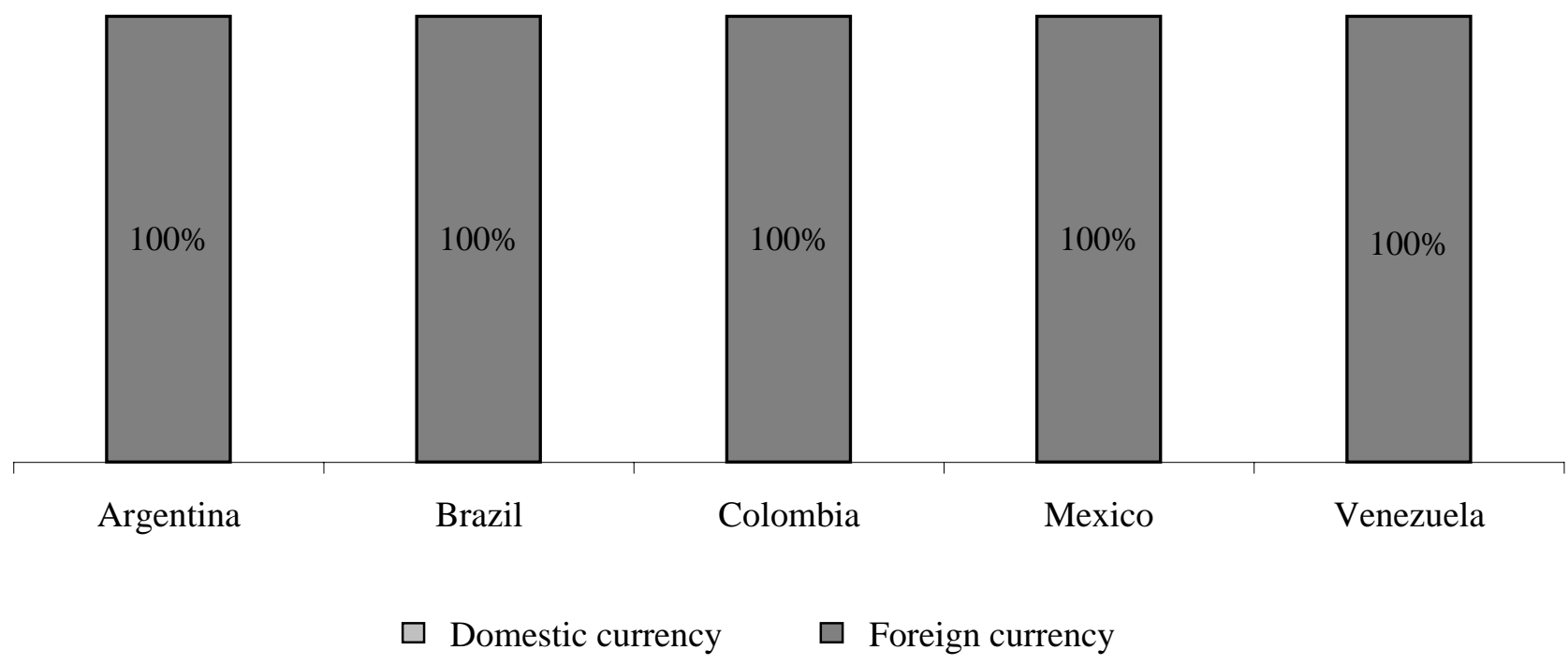

The figures show the shares of the amount issued of corporate bonds in 2000 denominated in domestic and foreign currency in international and domestic markets. To control for maturity, only bonds of maturity between one and four years are considered.

Source: Bloomberg 
Figure 8

Dollarization of Sovereign Bonds by Jurisdiction

Shares of Amount Issued in Foreign and Domestic Currencies - Maturity of 2-5 Years (2000-2002)

Domestic Market

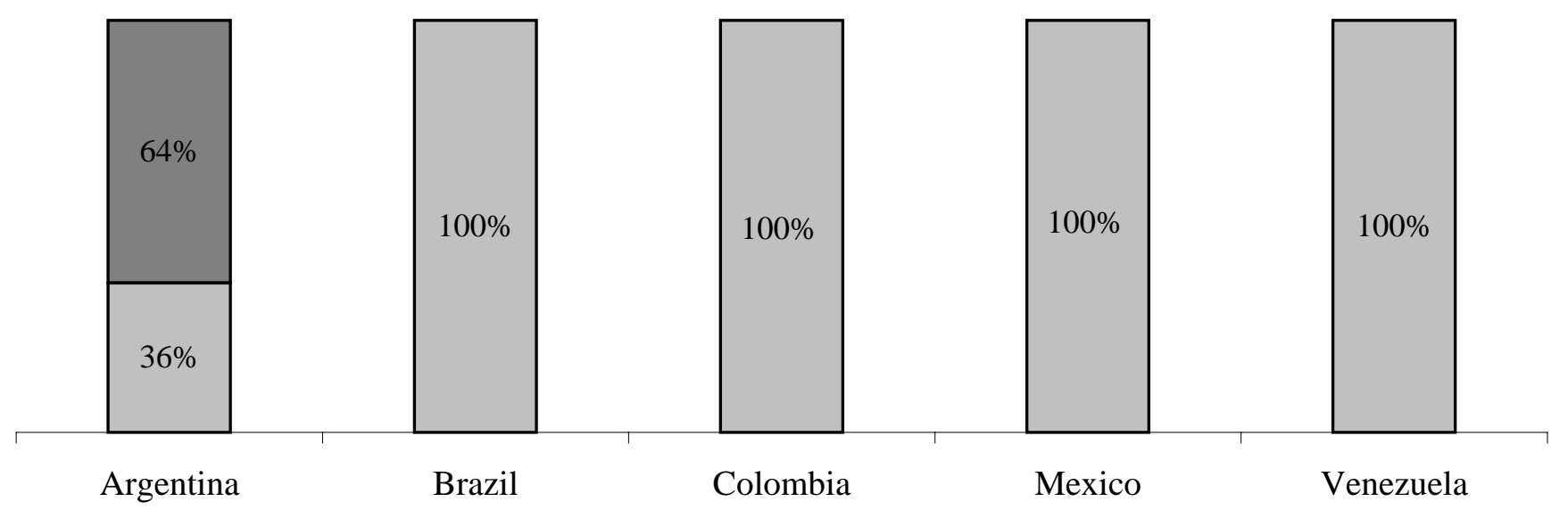

International Market

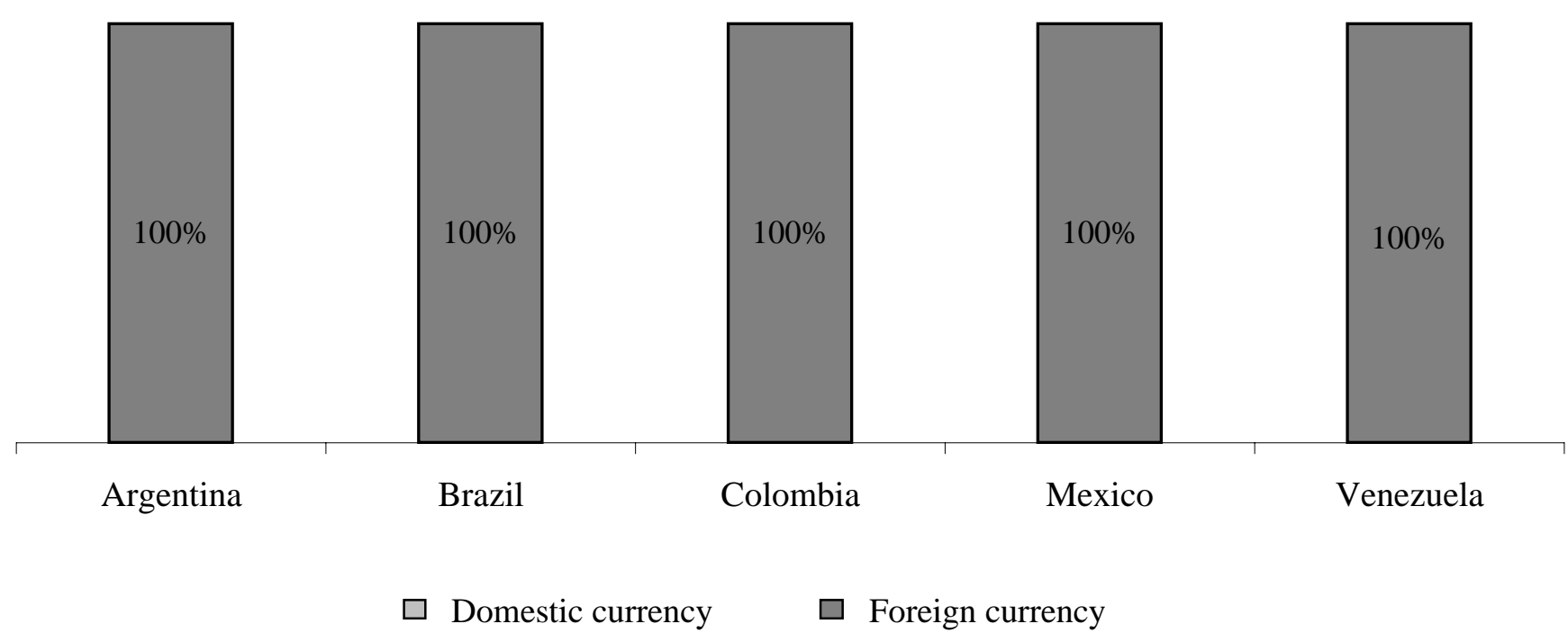

The figures show the shares of the amount issued of sovereign bonds in the period 2000-2002 denominated in domestic and foreign currency in international and domestic markets. To control for maturity, only bonds of maturity between two and five years are considered.

Source: Bloomberg 
Figure 9

\section{Peso and Dollar Deposits in Argentina After Convertibility}

\section{Evolution of Peso and Dollar Deposits (millions of dollars)}

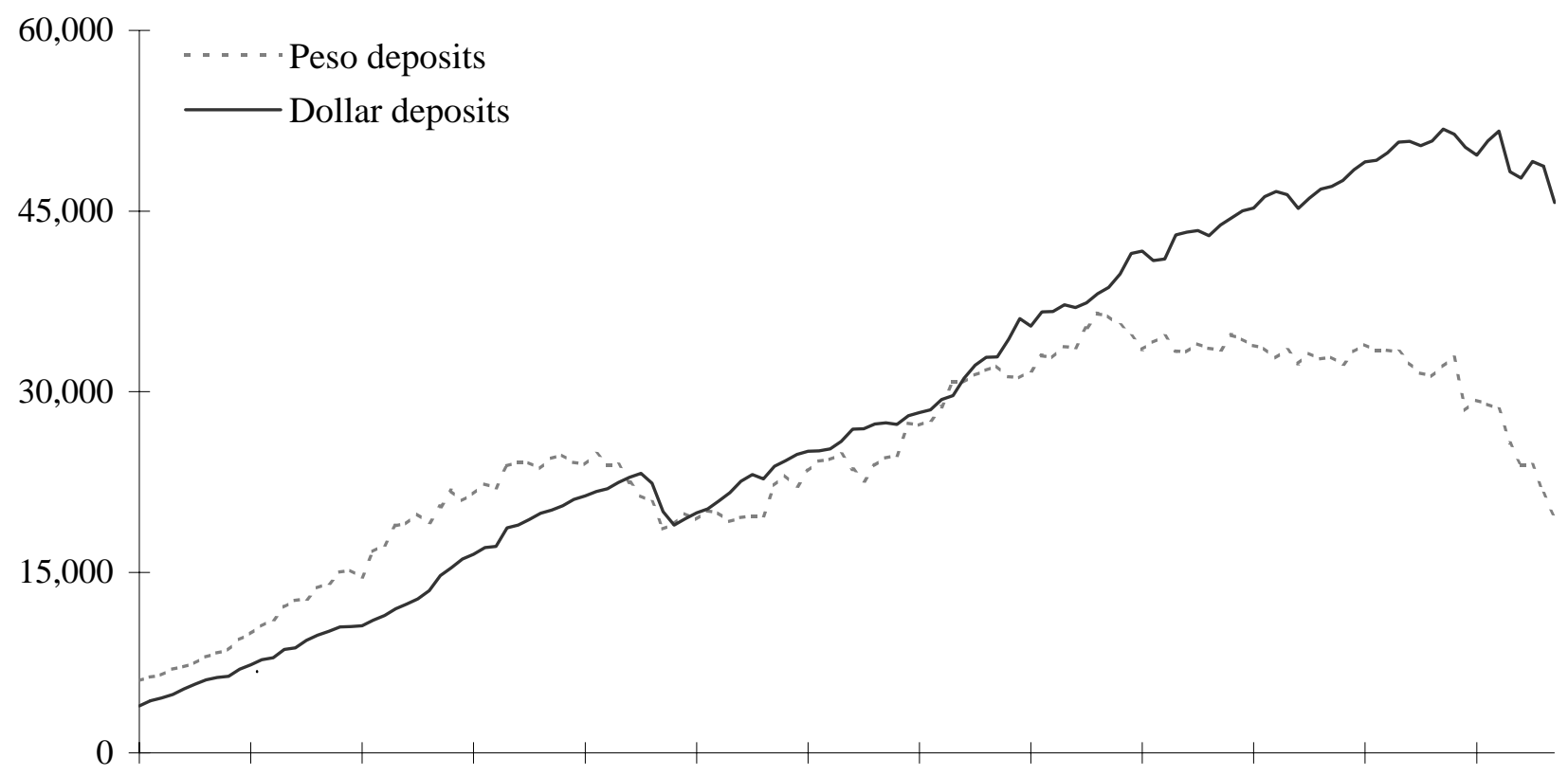

Apr-91 Feb-92 Dec-92 Oct-93 Aug-94 Jun-95 Apr-96 Feb-97 Dec-97 Oct-98 Aug-99 Jun-00 Apr-01

Share of Dollar Deposits over Total Deposits

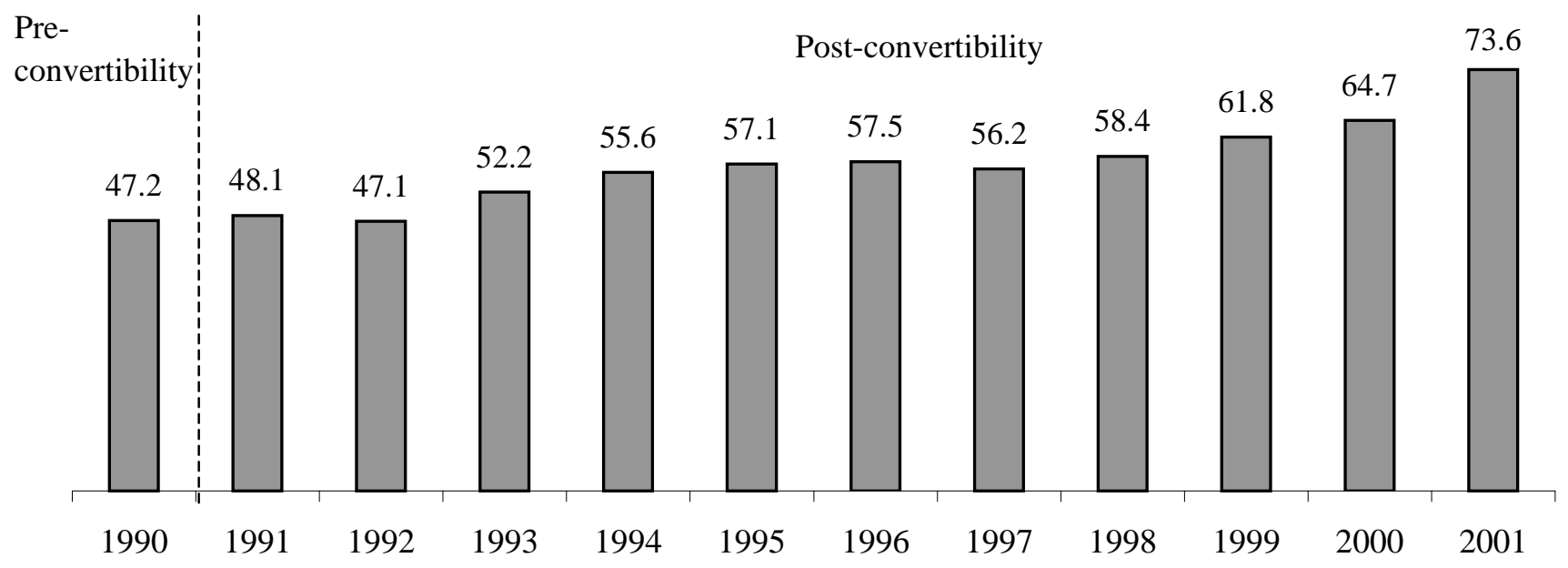

The figures show the evolution of peso and dollar deposits and the share of dollar deposits in Argentina after the approval of the Convertibility Law, which established the currency board and entered into effect in April 1991.

Source: Central Bank of Argentina 


\section{Figure 10}

\section{Distribution of Domestic Corporate Bonds by Currency and Maturity}

\section{Argentina (2000)}

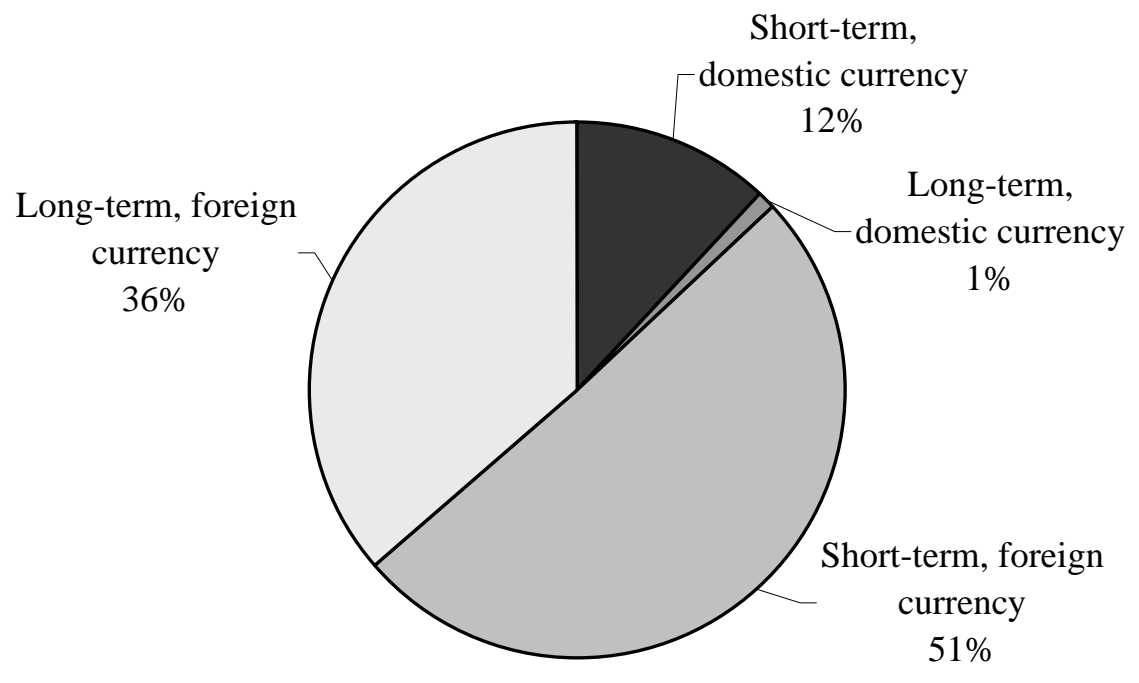

\section{Peru (2000)}

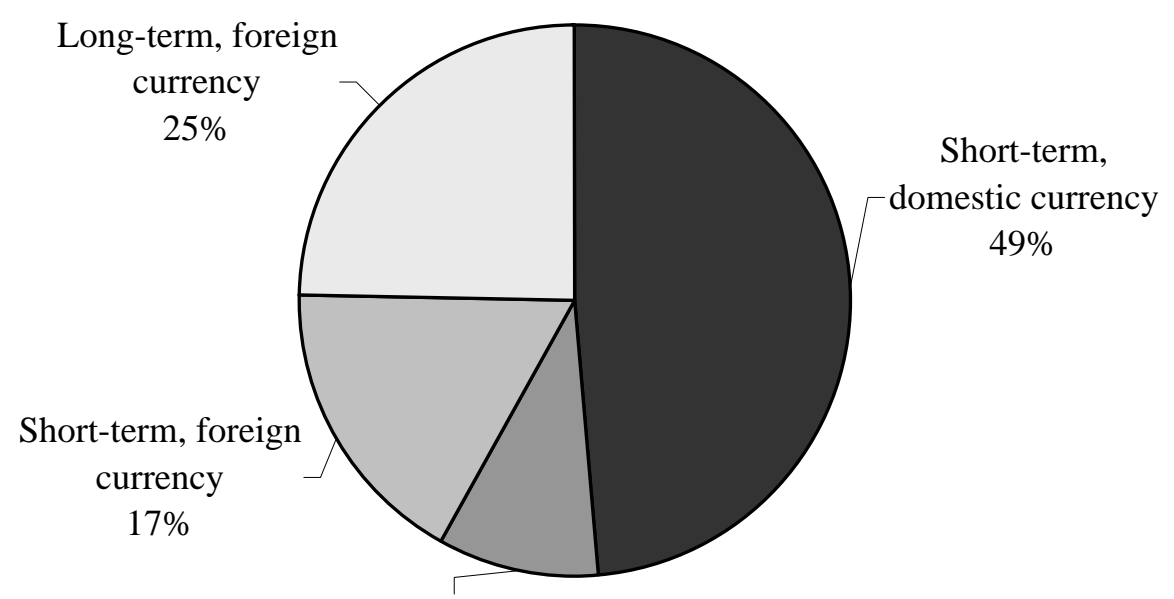

Long-term, domestic currency $9 \%$

The figures show the distribution of domestic corporate bonds issued in 2000 by currency and maturity in Peru and Argentina. Short-term bonds are defined as those with maturity up to five years. Bonds of maturity shorter than one year are excluded from the sample.

Source: Bloomberg 
Figure 11

Use of Currency and Duration under Systemic Risks

Dollarization and Trade Openness in Developed and Developing Countries (2001)

\begin{tabular}{lcc}
\hline & Developed countries & Developing countries \\
\hline Foreign currency deposits over total deposits & 8.3 & 31.5 \\
Exports over GDP & 50.5 & 35.5 \\
Exports plus imports over GDP & 97.7 & 77.6 \\
\hline
\end{tabular}

\section{Dollarization and Short Duration after Shocks}

Brazil: Composition of Domestic Federal Debt

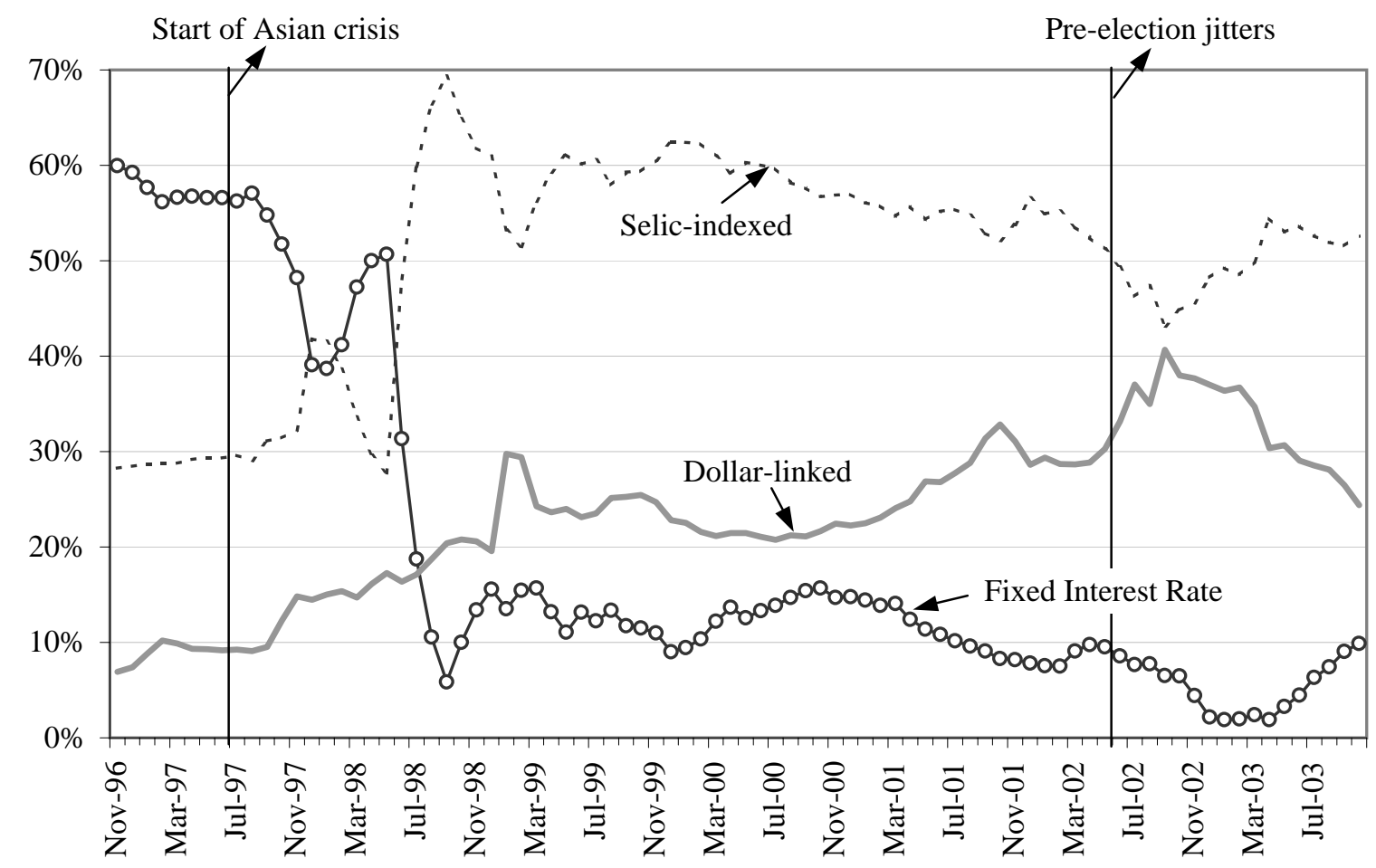

The top panel shows simple averages of dollarization of bank deposits and the trade share (measured as exports over GDP and as exports plus imports over GDP). The sample includes ten developed countries (Austria, Hong Kong-China, Denmark, Finland, Japan, Netherlands, Spain, Sweden, Switzerland, and United Kingdom) and 47 developing countries (Angola, Antigua and Barbuda, Argentina, Bangladesh, Barbados, Belize, Bhutan, Bolivia, Cambodia, Chile, China, Comoros, Congo Dem. Rep., Costa Rica, Dominica, Ecuador, Egypt Arab Rep., El Salvador, Guatemala, Guinea, Haiti, Honduras, Indonesia, Jamaica, Kenya, Lebanon, Malawi, Malaysia, Mexico, Mozambique, Nigeria, Paraguay, Peru, Philippines, Sao Tome and Principe, South Africa, St. Kitts and Nevis, St. Vincent and the Grenadines, Tanzania, Thailand, Trinidad and Tobago, Turkey, Uruguay, Venezuela, Vietnam, Yemen Rep., and Zambia). The bottom panel displays the evolution of the composition of Brazil's domestic federal debt. Data include only domestic federal debt held outside the central bank. Selic-indexed debt includes reference rate. After the pre-crisis jitters, the decrease in the selic-indexed debt and the increase in the dollar-linked debt are partly due to the use of currency swaps. The original selic-indexed and dollar-linked debt data were transformed to account for the effect of the currency swaps, which effectively converted selic-indexed debt into dollar-linked debt and viceversa.

Sources: International Financial Statistics (IFS), World Development Indicators (WDI) and Central Bank of Brazil 